\title{
Origin of red beds in the Paleoproterozoic Franceville Basin, Gabon, and implications for sandstone-hosted uranium mineralization
}

\author{
Bankole Olabode M. ${ }^{1,}{ }^{*}$, El Albani Abderrazak ${ }^{1}$, Meunier Alain ${ }^{1}$, Rouxel Olivier ${ }^{2}$, \\ Gauthier-Lafaye Francois ${ }^{3}$, Bekker Andrey ${ }^{4}$
}

${ }^{1}$ Univ Poitiers, CNRS, UMR 7285, Hydrasa IC2MP, Batiment B35,5 Ave Albert Turpain, F-86073

Poitiers, France.

2 IFREMER, Ctr Brest, F-29280 Plouzane, France.

${ }^{3}$ CNRS, UMR 7517, Lab Hydrol \& Geochim Strasbourg, F-67084 Strasbourg, France.

${ }^{4}$ Univ Calif Riverside, Dept Earth Sci, Riverside, CA 92521 USA.

* Corresponding author : Olabode M. Bankole, email address : olabode.bankole@univ-poitiers.fr

\begin{abstract}
:
Red beds are extensively used as evidence for an oxygenated atmosphere in the Paleoproterozoic. Red beds in the unmetamorphosed, ca. 2.15 Ga FA Formation of the Franceville Basin, Gabon were geochemically, petrographically, and mineralogically characterized to constrain the process of their formation and their relationship to atmospheric oxygenation in the early Paleoproterozoic. Petrographic observations indicate that ferric oxides are dispersed in clay filling intergranular pores and along platy cleavage in altered phyllosilicates. Grain-coating hematite is generally rare to absent in most samples suggesting hematite precipitation after sediment deposition and during burial diagenesis. Textures and geochemical data suggest that iron was likely sourced internally by alteration of iron-bearing minerals such as biotite and chlorite in sediments and redistributed in rocks during late diagenesis. Positive correlation between $\mathrm{Fe} / \mathrm{Mg}$ ratio and $\delta 56 \mathrm{Fe}$ values of bulk samples suggests mixing relationship with end members being authigenic hematite and iron-bearing silicates (biotite and chlorite). The lack of relationship between $\mathrm{Fe} 3+/ \mathrm{FeT}$ ratios and iron isotope compositions suggest that the isotopically heavy iron oxide was already present in the sediments during early diagenesis, and was incorporated into green (reduced) facies that likely replaced red facies during diagenesis and burial. Large range of $\delta 56 \mathrm{Fe}$ values extending towards positive values, up to +1 permil, is similar to that observed in Archean and Paleoproterozoic iron formations or modern groundwater-derived Fe-oxyhydroxides, suggesting partial oxidation of $\mathrm{Fe}$ under mildly oxidizing conditions during early diagenesis. In addition, positive correlation between $\mathrm{Cr} / \mathrm{Fe}$ ratios and iron isotope values, especially in the fine-grained sandstones and mudstones, is evidence for authigenic Cr enrichment under locally mildly-reducing conditions in a fluvial setting and strongly oxidizing conditions during weathering and riverine transport. Uranium released from the lower, fluvial oxidized sandstones and added to the reduced sandstones and silty mudstones in the upper tidal-deltaic sediments potentially resulted in a uranium mineralization of a sandstone-type in the FA Formation of the Franceville Basin.
\end{abstract}


Keywords : Red beds, atmospheric oxygenation, diagenesis, iron isotopes, Franceville Basin, oldest sandstone-type $U$ deposit 
Introduction

Red beds are sedimentary rocks, which are formed in oxidizing conditions with distinctive red color due to the presence of disseminated ferric oxides, typically hematite (Van Houten, 1973; Chandler, 1980; Turner, 1980; Eriksson and Cheney, 1992; Mucke, 1994). They are usually associated with variable proportions of intercalated drab (gray, green, brown, and black in color) strata or layers (Van Houten, 1973; Turner, 1980). In general, color variations in red beds have been ascribed to fluctuations in depositional or post-depositional redox conditions. They typically formed in fluvial, lacustrine, aeolian, and parallic environments that were developed in rapidly subsiding, fault-bounded basins in extensional tectonic settings (Turner, 1980). They may also occur in other sedimentary environments, such as along passive continental margins and in clastic wedges along edges of compressional mountain belts (Turner, 1980).

Time distribution of red beds plays an important role in the history of the atmosphere because it is widely believed that the onset of their deposition coincides with the irreversible oxygenation of the atmosphere called "the Great Oxidation Event (GOE)" (Holland, 2002; Bekker and Holland, 2012), and after that they are common for the rest of the Proterozoic (Chandler, 1980). Red beds in early Paleoproterozoic sedimentary rocks are thus good indicators for an oxygenated atmosphere. In addition, red beds are associated with a variety of economic deposits such as uranium, copper, zinc, lead, and hydrocarbon reservoirs (Metcalfe and others, 1994).

Although not formerly described as red beds, iron mobilization and re-precipitation in the red-colored sediments of the ca. $2.15 \mathrm{Ga}$ FA Formation in the Paleoproterozoic Franceville Basin, Gabon has been linked to circulation of oxidized groundwater during the GOE (Gauthier-Lafaye, ms, 1986; Gauthier-Lafaye and Weber, 1989, 2003; Gauthier-Lafaye, 2006; Mathieu and others, 2000). According to these models, oxidation of the FA sediments is thought to have occurred long after their deposition when circulating, oxidized hydrothermal fluids leached and remobilized $U$ from the lower conglomeratic sandstones and migrated 
upward along fractures during basin inversion. The dissolved $U$ was redeposited at redox boundaries between the FA Formation and the overlying FB Formation, where U-rich oxidized fluids interacted with organic matter or hydrocarbons from the FB Formation. Mossman (2001), Mossman and others (2005) used paragenesis of solid bitumens while Dutkiewicz and others (2007) used fluid inclusion and microthermometric data to infer two episodes of hydrocarbon migration from the FB Formation to the FA Formation in the Franceville Basin. The first episode is indicated by trapping of hydrocarbon in the intergranular pore spaces of the FA Formation sandstones (Mossman, 2001; Mossman and others, 2001) and occurred during burial diagenesis at temperatures between 130 and $200^{\circ} \mathrm{C}$ (Dutkiewicz and others, 2007). The second episode, presumed as the main period of hydrocarbon migration, is represented by solidified pyrobitumen in the intragranular pore spaces (Mossman, 2001; Mossman and others, 2005) and occurred at temperature between 250 and $350^{\circ} \mathrm{C}$ during late diagenesis at maximum burial of sediments (Dutkiewicz and others, 2007).

$\mathrm{U}$ deposits in the Franceville Basin are located at Bangombé, Boyindzi, Mikouloungou, Mounana, Okelobondo, and Oklo (fig. 1). The U mineralization has a complex history and the $\mathrm{U}$ is presumed to be sourced from the Archean granitoids and altered monazite in the basal fluvial conglomeratic sandstones of the FA Formation (GauthierLafaye, ms, 1986; Gauthier-Lafaye and Weber, 1989; Cuney and Mathieu, 2000; Mathieu and others, 2001). Despite these inferences, the origin of hematite in the red-colored FA sediments, its genetic relationship with $U$ mineralization, original color of sediments at the time of deposition, and the oxidation state of the fluid that first migrated through the FA Formation remains unknown and poorly constrained.

Mechanisms involved in formation of $U$ deposits and amount of $U$ resources vary considerably through geologic time from the Mesoarchean to the present (Cuney, 2010). Three age-controlled U deposit types were documented by Cuney (2010): (1) placer deposits 
of detrital uraninite in sedimentary basins formed before the GOE (for example, the Witwatersrand basin, South Africa and the Huronian basin, Canada); (2) unconformity-type deposits occurring along the unconformity between altered crystalline basement rich in reductants such as graphitic and sulfidic schists and overlying, oxidized clastic sediments (for example, the Middle Proterozoic Athabasca Basin, Canada and McArthur River Basin, Australia); and (3) sandstone-hosted deposit of the Phanerozoic age (for example, Chu-Sarysu Basin, Kazakhstan and Wyoming Basin, USA). Such progression in U deposits through time has been linked to the development of oxygenated atmosphere and appearance of land plants. Sandstone-hosted U deposits are typically thought to be exclusively Phanerozoic in age, appearing after the evolution of terrestrial vegetation. $U$ mineralization in sandstone deposits usually forms by reduction of highly soluble hexavalent $U\left(U^{6+}\right)$ to tetravalent $U$ $\left(\mathrm{U}^{4+}\right)$ at redox interface in generally medium- to coarse-grained, permeable sandstones that are interbedded with or bounded by less permeable rocks. $\mathrm{U}$ is leached from source rocks by migrating oxidized fluids (either along fractures or through pore spaces) and precipitated when the fluids interacts with reducing agents (for example, carbonaceous materials, hydrocarbons, pyrites, hydrogen sulfide, or ferromagnesian minerals) within the sandstones. Although it is generally considered that sandstone-hosted deposits formed exclusively after the appearance of land plants, providing localized reduction centres, Cuney (2010) suggested that petroleum could be another reducing agent to form sandstone-hosted deposit. The Paleoproterozoic Franceville Series currently hosts the oldest known U deposit formed after the GOE, and the deposit is not hosted at the unconformity with the Archean basement, but exclusively in siliciclastic sediments. It can thus be argued that petroleum migration resulted in the origin of the oldest sandstone-hosted $U$ deposit long before terrestrial vegetation evolved.

In order to draw any connection between the occurrence of red beds, sandstone-hosted deposit, and the redox state of the atmosphere, it is important to understand the composition 
of the sediments and their post-depositional history. Here, we have studied the sediments of Paleoproterozoic FA Formation in the Franceville Basin, which represents one of the world's oldest unmetamorphosed sedimentary successions with well-preserved red-colored sediments, and therefore provides insight into the origin of red beds on the early Earth. The petrography and depositional framework of the FA Formation, especially in the study area in the central part of the basin have been studied in detail by Weber (ms, 1968), Haubensack (ms, 1981), Gauthier-Lafaye (ms, 1986), Gauthier-Lafaye and Weber (1989), Ossa Ossa (ms, 2010), Bankole and others (2015), and Bankole (ms, 2015).

This study presents combined petrographic, whole-rock and stable $\mathrm{Fe}$ isotope geochemical data to constrain the origin and the environmental conditions for the development of hematite (specifically relative timing and mechanism for its formation), and the sequence of diagenetic redox changes reflected in colors of the sediments in the Paleoproterozoic FA Formation, Franceville Basin, Gabon. The Franceville red beds are particularly important since they are thought to have formed in the middle part of the GOE. They are associated with the $U$ deposits that are unique since they are not placer- or unconformity-type deposits, but are hosted in a siliciclastic succession, and yet are too old to be a classical sandstone-hosted $U$ deposit since they precede the appearance of terrestrial vegetation by more than $1.5 \mathrm{Ga}$.

\section{GEOLOGICAL BACKGROUND}

The Paleoproterozoic Franceville Basin is one of the four basins that constitute the extensive Francevillian Series in south-eastern Gabon (figs. 1A and 1B). The Francevillian Series is a 1 to $2.5 \mathrm{~km}$ thick unmetamorphosed volcanoclastic sedimentary succession deposited during the early Paleoproterozoic at ca. 2.15 Ga (Gauthier-Lafaye and Weber, 1989; Bros and others, 1992; Gauthier-Lafaye, 2006; Préat and others, 2011; El Albani and others, 2014). The lithostratigraphy of the Francevillian Series is most complete in the Franceville 
and Okondja basins, and has been divided into five different formations: FA to FE (fig. 2; Weber; ms, 1968).

The FA Formation, which if the focus of this study, unconformably overlies the Archean granitoid basement rocks (Feybesse and others, 1998) and is predominantly composed of fine- to coarse-grained sandstones and conglomeratic sandstones that contain minor interbedded mudstones. Due to the complex lithofacies variations in the central part of the basin, the spatial distribution of the FA Formation rocks have been subdivided into five different zones that correspond to different sedimentary environments (fig. 3; Haubensack, ms, 1981; Gauthier-Lafaye, ms, 1986; Gauthier-Lafaye and Weber, 1989). The lowermost Zone 4 is composed mainly of medium- to coarse-grained sandstones and conglomeratic sandstones with minor thin interbedded mudstones. The Otobo series is composed of alternating sandstones and fine- to coarse-grained sandstones and mudstones in a coarseningupward sequence. Zone 3 is composed mainly of thick bedded, fine-grained sandstones with interbedded medium- to coarse-grained sandstones and mudstones. Zone 2 is predominantly fine- to coarse-grained sandstones with minor interlayered mudstones, while Zone 1 is dominated by medium- to coarse-grained sandstones. Depositional setting of the FA Formation rocks have been interpreted to have evolved from fluvial at the base through deltaic and tidal-deltaic in the middle to fluvio-deltaic or coastal deposits in the upper part (Haubensack, ms, 1981; Gauthier-Lafaye, ms, 1986; Gauthier-Lafaye and Weber, 1989).

The FA Formation sedimentary rocks have been subjected to a complex diagenetic alteration processes (Gauthier-Lafaye, ms, 1986; Ossa Ossa and others, 2014; Bankole and others, 2015). The colors typically range from red to green to black from the base to the top. However, in details, the color is independent of rock types and does not follow this stratigraphic trend; color changes cut through stratigraphic bedding with reduction and oxidation spots formed in some instances due to diagenetic overprinting (Haubensack, ms, 1981; Gauthier-Lafaye and Weber, 2003). The basin's uranium deposits are commonly 
associated with solidified hydrocarbon within tectonic structures and sit close to the redox boundary between the FA and FB formations (Gauthier-Lafaye, ms, 1986; Gauthier-Lafaye and Weber, 1989 and 2003). The hydrocarbon is thought to have migrated from the FB Formation into the FA Formation along micro-fractures where the FB Formation is structurally positioned below or adjacent to the FA Formation (Gauthier-Lafaye, ms, 1986; Gauthier-Lafaye and Weber, 1989 and 2003). Uranium mineralization in the FA Formation yields a U-Pb age of $2050 \pm 30 \mathrm{Ma}$ for ore formation (Gancarz, 1978), and $1950 \pm 30 \mathrm{Ma}$ for remobilization, which coincides with the age of the natural nuclear fission (Ruffenach, 1978; Holliger, 1988; Naudet, 1991). The depositional age of the FA Formation remains poorly constrained.

The marine FB Formation overlies the predominantly fluvial FA Formation and consists of alternating sandstones and black mudstones (shale and siltstone) (AzzibrouckAzziley, ms, 1986; Gauthier-Lafaye, ms, 1986; Gauthier-Lafaye and Weber, 1989; Pambo, ms, 2004). The black mudstones are rich in organic matter with total organic carbon content up to10\% (Cortial and others, 1990). Timing of petroleum generation and early diagenesis in the FB Formation is constrained by Sm-Nd isotopic ages of $2099 \pm 115 \mathrm{Ma}$ and $2036 \pm 79 \mathrm{Ma}$ on $<0.4 \mu \mathrm{m}$ and $<0.2 \mu \mathrm{m}$ clay fractions, respectively (Bros and others, 1992). Authigenic illites from $<1.5 \mu \mathrm{m}$ and $<2.0 \mu \mathrm{m}$ clay fractions from the upper part of the FB1 unit (fig. 2) gave an apparent $\mathrm{Rb}-\mathrm{Sr}$ isochron date of $1870 \pm 50 \mathrm{Ma}$ for the late diagenesis (Bonhomme and others, 1982).

The overlying FC Formation consists of massive dolostones and thick, banded stromatolitic cherts that are interpreted as shallow-marine deposits (Weber, ms, 1968; Gauthier-Lafaye and Weber, 2003; Préat and others, 2011). The FD Formation is predominantly black shale succession with thin interbedded fine- to medium-grained sandstones capped by welded tuff. It was deposited in a shallow-marine, reducing environment with episodic input of volcanic materials (Thiéblemont and others, 2009). The 
youngest formation, FE, is composed of epiclastic, fine-grained sandstones and interbedded shale (Gauthier-Lafaye and Weber, 1989; 2003; Préat and others, 2011; Thiéblemont and others, 2014) and probably developed via erosion of the Paleoproterozoic Ogooué orogenic belt present to the northwest of the Franceville Basin (fig. 1; Thiéblemont and others, 2009).

\section{SAMPLES AND METHODS}

Samples and Study Area

About seventy sandstone and mudstone samples of the FA Formation from eight drill holes in the central part of the basin (GR3, GR 15, GR 23, GR 22, GR 25, KA 13, KA 27, and KA 29; fig. 1) were examined in this study. Six of the studied drill holes form a north to south transect (fig. 3). The thickness of the FA Formation in the investigated drill holes varies from 500 to $1000 \mathrm{~m}$. Among the studied drill holes, complete core coverage of the FA Formation is only available for GR 15 drill hole (fig. 1), which was drilled to $993 \mathrm{~m}$ depth and stopped before the intersection with the basement. The basal $\sim 500 \mathrm{~m}$ in GR 15 drill hole (fig. 4) are mainly red to pink coarse- to medium-grained sandstones and conglomeratic sandstones with minor thin interbedded mudstones. These are followed by $\sim 100 \mathrm{~m}$ of alternating green and red to purple mudstones and fine- to coarse-grained sandstones that are overlain by $\sim 200 \mathrm{~m}$ of predominantly red-colored, fine-grained sandstones with interbedded medium- to coarsegrained sandstones and mudstones. The uppermost part consists of $\sim 200 \mathrm{~m}$ of alternating green and gray to black fine- to coarse-grained sandstones with interbedded mudstones towards the top.

\section{Analytical Methods}

Petrography.-Polished thin sections of representative samples were examined with optical microscopy (in transmitted and reflected light) and scanning electron microscopy (SEM) equipped with energy dispersive spectroscope (EDS) for mineralogical and textural 
characterization, and analysis of elemental mineral composition. Selected representative thin sections were carbon coated and examined in SEM-EDS backscattered electron (BSE) imaging mode using a JEOL JSM 6400 electron microscope operated at accelerating voltage of $15 \mathrm{Kv}, 1 \mathrm{nA}$ probe current, and working distance of $16.5 \mathrm{~mm}$ at the University of Poitiers, France.

$X$-ray diffraction $(X R D) .-X R D$ was performed on selected samples for bulk and clay mineral composition analyses. XRD analyses were carried with a Bruker D8 ADVANCE diffractometer using $\mathrm{CuK} \alpha$ radiation, operated at $40 \mathrm{kV}$ and $40 \mathrm{~mA}$ and $0.025 \mathrm{~s}$ per step counting times. The $<2 \mu \mathrm{m}$ clay mineral fraction was extracted by dispersion with an Elma S60 ultrasonic agitation device of gently hand crushed bulk samples in deionized water without any chemical pre-treatment (Moore and Reynolds, 1997). The dispersed suspensions were gravity settled at a controlled room temperature of $20^{\circ} \mathrm{C}$ and centrifuged to separate $<2$ $\mu \mathrm{m}$ clay fraction. Oriented slides of $<2 \mu \mathrm{m}$ clay fraction were prepared by sedimentation on glass slide and analyzed over the $2-35^{\circ} 2 \theta$ angular range after air-drying at room temperature (AD), ethylene glycol (EG) treatment, and heating to $550^{\circ} \mathrm{C}$ for $4 \mathrm{hrs}$. The powdered bulk rock samples were examined over the $2-65^{\circ} 2 \theta$ angular range. X'pert High Score software was used for indexing of diffraction peaks and identification of mineral phases by comparison with International Centre for Diffraction Data (ICDD) files.

Whole rock analyses. - Whole-rock geochemical analyses of major and trace elements including the rare earth elements were performed on selected samples at Service d'Analyse des Roches et des Mineraux (SARM) of the Centre des Recherches Petrographiques et Geochemiques (CRPG), Nancy, France. Fifty representative samples were carefully selected to represent different rock types and color variations. After powdering and homogenization in agate mortar, each sample was fused with lithium metaborate $\left(\mathrm{LiBO}_{2}\right)$ and dissolved in nitric acid. Major element contents were measured by inductively-coupled plasma atomic emission spectrometry (ICP-AES), while trace element, including rare earth element, concentrations 
were measured by inductively-coupled plasma mass spectrometry (ICP-MS). All major

262 elements and few trace elements (U, Th, and $\mathrm{Cr}$ ) are reported in this study. In addition, $\mathrm{FeO}$ concentrations were also measured for twenty-five powdered samples by titration. Ferric iron oxide contents $\left(\mathrm{Fe}_{2} \mathrm{O}_{3}\right)$ were determined as the difference between the concentration of total iron $\left(\mathrm{Fe}_{2} \mathrm{O}_{3}\right)_{\mathrm{T}}$ and ferrous iron $(\mathrm{FeO})$.

Fe Isotope analysis. - Iron isotope ratios were measured for thirty-two representative whole-rock samples selected based on their color: red and green. The laboratory procedure for sample preparation, chemical purification, and $\mathrm{Fe}$ isotope analysis is described in details in Rouxel and others (2005, 2008a) and Craddock and Dauphas (2011). The Fe isotope ratios $\left({ }^{56} \mathrm{Fe} /{ }^{54} \mathrm{Fe}\right.$ and $\left.{ }^{57} \mathrm{Fe} /{ }^{54} \mathrm{Fe}\right)$ were measured on a multiple-collector ICP-MS (Neptune, Thermo Scientific) operated at the Pole Spectrometry Ocean, IFREMER, Brest, France. The Neptune instrument permits high-precision measurements of $\mathrm{Fe}$ isotope ratios without argon interferences by using high mass-resolution mode. The instrument was operated on medium and high resolution modes to resolve the isotopes of interest from the polyatomic interferences from $\mathrm{ArN}^{+}, \mathrm{ArO}^{+}$, and $\mathrm{ArOH}^{+}$(Weyer and Schwieters, 2003). Instrumental mass-discrimination was corrected by sample-standard bracketing technique combined with the use of $\mathrm{Ni}$ as an internal standard for mass bias correction as described in Poitrasson and Freydier (2005). Fe isotope data were normalized and are reported relative to the international Fe isotope standard IRMM-14, and calculated using the following notations:

$$
\begin{aligned}
\delta^{56} \mathrm{Fe} & =\left[\left({ }^{56} \mathrm{Fe} /{ }^{54} \mathrm{Fe}\right)_{\text {sample }} /\left({ }^{56} \mathrm{Fe} /{ }^{54} \mathrm{Fe}\right)_{\text {IRMM-14 }}-1\right] * 10^{3} \\
\delta^{57} \mathrm{Fe} & =\left[\left({ }^{57} \mathrm{Fe} /{ }^{54} \mathrm{Fe}\right)_{\text {sample }} /\left({ }^{57} \mathrm{Fe} /{ }^{54} \mathrm{Fe}\right)_{\text {IRMM-14 }}-1\right] * 10^{3}
\end{aligned}
$$

Based on duplicate analyses of BHVO-2 georeference material, yielding the average $\delta^{56} \mathrm{Fe}$ value of $0.11 \%$ (Barrat and others, 2015), an external precision is $0.07 \%$ ( $2 \sigma$ standard deviation) under the analytical conditions used in this study. 
The FA Formation rock types typical for the studied area are essentially fine- to coarse-grained sandstones, conglomeratic sandstones, siltstones and mudstones. In this study, we divide the rock types into 2 main groups based on their grain size: granular (medium- to coarse-grained sandstones and conglomerate) and fine-grained (mudstones, siltstones, and fine-grained sandstones). The granular group includes mostly massive, structureless, and cross-bedded indurated rocks (figs. 5A, 5B, and 5C) that dominate the lower fluvial lithofacies. Rocks from this group also alternate with rocks from the fine-grained group in the middle, tidal-deltaic and upper, fluvio-deltaic lithofacies (figs. 3 and 4). They are mostly composed of poorly to moderately sorted, texturally immature to sub-mature, arkose to subarkose sandstones. The fine-grained rocks are massive (fig. 5D), planar bedded (fig. 5E) with internally laminated ripples (fig. 5F) and slump structures, lenticularly bedded or crossbedded (fig. 5G). They occur as rare interbedded layers in the lower fluvial lithofacies, but are common in the middle deltaic and tidal-deltaic lithofacies, as well as in the upper fluviodeltaic lithofacies (fig. 3). The fine-grained group mostly consists of greywackes composed of poorly-sorted, angular detrital grains that are contained in fine-grained argillaceous matrix.

The detrital minerals in the sediments are dominated by quartz followed by feldspars (K-feldspar and plagioclase) and micas (muscovite and biotite) present in substantial amounts. $\mathrm{K}$-feldspar is present in all the sedimentary units while plagioclase (mostly albite) is very scarce in the lower fluvial lithofacies, but common in the middle to upper deltaic and tidaldeltaic facies. Accessory minerals include heavy minerals such as zircon, rutile, thorite, monazite, ilmenite, and apatite. Lithic fragments are more common in the lower fluvial lithofacies. The detrital and heavy minerals have experienced various degrees of compaction, dissolution, and replacement by authigenic mineral phases. 
The authigenic minerals in the sediments include iron oxide (hematite), anhydrite,

barite, calcite, chlorite, illite, pyrite, gypsum, and quartz overgrowths, and they vary considerably with depth and color. Variations in sediment color (fig. 5) are due to the difference in the distribution of the authigenic minerals, especially iron oxide. Four diagenetic facies are distinguished: red, green, black/gray, and the less common white (fig. 5B).

Red (oxidized) facies. - Sediments of these facies are red to pink or purple in core samples, and are mostly found in the lower fluvial, deltaic, and tidal-deltaic lithofacies. There seems to be a strong dependence of color on grain size in that the fine-grained sediments have stronger red-color saturation than the granular sediments. Hematite in the fine-grained sediments commonly occurs as finely dispersed grains in the argillaceous matrix, replacement of mica (mostly biotite) along cleavage planes (figs. 6A and 6B), and filling of pore spaces. In rare instances, hematite pseudomorphs of altered trellis-type ilmenite are also present (fig. 6C).

In the granular, red tidal-deltaic lithofacies, in addition to being dispersed in the argillaceous matrix and replacing mica, hematite also occur as pore-filling crystals (fig. 6D), coating detrital grains (figs. 6E and 6F), and postdating authigenic carbonate and anhydrite cements (see appendix fig. A-1A and 1B). Thin coatings of hematite on detrital grains (quartz and feldspar) are rare and mostly poorly developed when observed. The coatings are sometimes developed at grain contacts (figs. 6D, 6E and 6F) and covered by thin quartz overgrowths or encased by calcite cement (fig. 6E). Quartz overgrowths and calcite cement preserve reddish hematite rims in such cases. K-feldspar and albite grains have been highly altered and are mostly replaced by illite and calcite. Chlorite was observed only in few instances. Biotite is altered and commonly replaced by titanium oxide and hematite. In few instances, euhedral hematite grains occur within massive hematite cement and clay minerals. The carbonate is mainly non-ferroan calcite and generally present in small amounts filling pores spaces (fig. 6E). 

commonly occurs in association with titanium oxide along open cleavages and surfaces of mica (mostly muscovite) (see appendix, figs. A-1C and 1D). Pore-filling and grain-coating hematite is very rare to absent in the lower, fluvial granular rocks. Carbonates and chlorite are also absent while illite is the only clay mineral.

Anhydrite is abundant authigenic cement in both the granular lower fluvial and tidaldeltaic lithofacies. It commonly fills pore spaces with poikilotopic texture in most cases, enclosing corroded detrital quartz and feldspar, and often in association with later-formed barite. Anhydrite appears to postdate quartz overgrowths in most occurrences. Hematite postdating and predating anhydrite was also observed in the granular red tidal-deltaic lithofacies.

Green and black/gray (reduced) facies. - Sediments of these facies dominate the upper part of the formation in the fluvio-deltaic lithofacies. They also occur sporadically within the reddish tidal-deltaic and deltaic lithofacies in the middle part of the formation, mostly as green reduction spots or zones (Fig. 5D and H). Hematite is very rare in these greenish and blackish facies. Pyrite occurs as euhedral to amorphous, secondary pore-filling crystals (fig. 6G). In few instances, pyrite occurs along grain edges replacing detrital grains, and also in association with chlorite. Carbonates consist essentially of dolomite with traces of non-ferroan calcite. Illite and Fe-rich chlorites are present in varying proportions and dominate the pore spaces. In the green-colored samples, Fe-rich chlorite is abundant predominantly in the matrix. Biotite, albite and K-feldspars are variably preserved with highly chloritized to partly altered varieties. Gypsum and barite are present in small amounts filling pore spaces in few green samples. The pore space of the gray to black samples is partially filled with solidified pyrobitumen (Fig. 6H). 
pyrite are completely absent, and illite, anhydrite, and barite are the main minerals in cement with well-preserved secondary pore spaces.

The paragenetic sequence of the authigenic minerals in relation to fluid migration and uranium mineralization in the FA Formation in the central part of the basin is presented in figure 7 .

Clay Mineralogy and Chemistry

XRD analysis of oriented clay fraction $(<2 \mu \mathrm{m})$ of representative samples indicates that illite and chlorite are the only clay minerals in the samples with no evidence of illitesmectite mixed-layer clay minerals (fig. 8). While illite is present in all lithofacies, chlorite is restricted to the tidal-deltaic and fluvio-deltaic lithofacies, and is less common in the redcolored facies. XRD patterns (fig. 8), coupled with compositional data (fig. 9; table A-1), show that chlorite in the fine-grained samples, regardless of their color, is Fe-rich (chamosite) as indicated by the relatively strong even-order peaks relative to odd-order peaks. On the other hand, chlorite in the granular, red samples is Mg-rich chlorite (clinochlore) as pointed by strong odd- and even-order peaks (fig. 8 and 9). Petrographic evidence reveals that both illite and chlorite occur as feldspar and mica replacements as well as pore fillings in the reduced facies. Although very rare and small in size, chlorite in the red-colored facies is mainly found within the matrix.

\section{Whole-rock geochemistry}

Analyses were made on 50 selected, representative red (24), green (9), and gray to black (17) samples. The geochemical data (see appendix table A-2) and scatter diagrams for major elements are shown on figure 10. Major oxides were normalized to silica to account for "dilution" with quartz. Concentrations of major oxides in fine-grained sediments appear to be independent of color. Granular sediments are characterized by high and variable 
concentrations of $\mathrm{SiO}_{2}$ and $\mathrm{CaO}$ (figs. 10A and 10B), but lower $\mathrm{Al}_{2} \mathrm{O}_{3}$ (fig. 10A), $\mathrm{K}_{2} \mathrm{O}$ (fig. 10C), $\mathrm{Fe}_{2} \mathrm{O}_{3 \mathrm{~T}}$ (fig. 10D), and $\mathrm{TiO}_{2}$ contents (fig. 10E) compared to the fine-grained sediments. Samples have variable $\mathrm{MgO}$ and $\mathrm{Na}_{2} \mathrm{O}$ concentrations (figs. $10 \mathrm{~F}$ and $10 \mathrm{G}$ ), but the average content of $\mathrm{Na}_{2} \mathrm{O}$ tends to decrease with decreasing grain size while concentration of $\mathrm{MgO}$ tends to increase with decreasing grain size.

$\mathrm{Al}_{2} \mathrm{O}_{3}$ content exhibits strong negative relationship with $\mathrm{SiO}_{2}$ (fig. 10A), which is typical of siliciclastic sediments. $\mathrm{SiO}_{2}$-normalized $\mathrm{Al}_{2} \mathrm{O}_{3}$ exhibits strong positive correlation with $\mathrm{K}_{2} \mathrm{O}$ (fig. 10C) in all rock types. $\mathrm{CaO}$ shows no correlation with $\mathrm{Al}_{2} \mathrm{O}_{3}$ (fig. 10B) and other major oxides, with a large spread in the granular sediments suggesting that these oxides are hosted in different minerals. $\mathrm{Fe}_{2} \mathrm{O}_{3 \mathrm{~T}}$ shows a moderate correlation with $\mathrm{Al}_{2} \mathrm{O}_{3} / \mathrm{SiO}_{2}$ in the granular sediments, but exhibit no significant trend in the fine-grained sediments (fig. 10D). $\mathrm{TiO}_{2}$ displays significant positive correlation with $\mathrm{Al}_{2} \mathrm{O}_{3}$ in the granular sediments and in some fine-grained sediments (fig. $10 \mathrm{E}$ ). $\mathrm{Na}_{2} \mathrm{O}$ and $\mathrm{MgO}$ do not show any relationship with $\mathrm{Al}_{2} \mathrm{O}_{3}$ in all rock types (figs. $10 \mathrm{~F}$ and $10 \mathrm{G}$ ). These scatter diagrams indicate that the different geochemical characteristics exhibited by major elements might be controlled by mineralogy (for example, type of authigenic cement) and grain size. High content of $\mathrm{CaO}$ in the granular sediments might be related to carbonate and sulfate cements, whereas $\mathrm{K}_{2} \mathrm{O}, \mathrm{Al}_{2} \mathrm{O}_{3}$, and $\mathrm{TiO}_{2}$ contents appear to be controlled by silicates (mostly illites and K-feldspars) in all sediments. $\mathrm{MgO}$ and $\mathrm{Fe}_{2} \mathrm{O}_{3 \mathrm{~T}}$ are mainly hosted in silicate minerals such as biotite and chlorite. $\mathrm{Fe}_{2} \mathrm{O}_{3}$ and $\mathrm{FeO}$ do not display any significant relationship with other major elements and the fine-grained samples are more enriched in $\mathrm{Fe}_{2} \mathrm{O}_{3}$ relative to the granular samples, and most of the finegrained, red facies have higher $\mathrm{Fe}_{2} \mathrm{O}_{3}$ contents than fine-grained, green facies (fig. $10 \mathrm{H}$ ). Based on the $\mathrm{Fe}_{2} \mathrm{O}_{3}$ and $\mathrm{FeO}$ variations (fig. 10H), high $\mathrm{Fe}_{2} \mathrm{O}_{3}$ contents in most of the finegrained sediments reflect hematite enrichment, while Fe in the granular and few fine-grained samples is likely hosted by silicates or magnetite. 

oxidation state, but are somewhat grain size-dependent, in that fine-grained sediments have higher concentrations than sandstones with few exceptions (see appendix TA-2). U/Th ratios in the fine-grained samples range from 0.15 to 0.47 , whereas the granular samples have U/Th

420

421 ratios ranging from 0.15 to 0.69 . There is no significant difference in U/Th between the finegrained and granular sediments with the exception of three samples: lower fluvial, red-colored granular sample GR 15 711.1, enriched in REE, has the lowest U/Th (0.03) and appears to be U-depleted, while gray-black, granular KA 29-134.6 and gray-black, fine-grained KA 27114.75 samples from the upper part of the tidal-deltaic lithofacies are relatively enriched in $\mathrm{U}$ with U/Th of 10.17 and 3.19, respectively (fig. 11).

\section{Fe content and Fe isotope composition}

Most of the fine-grained red (oxidized) samples have higher total iron $\left(\mathrm{Fe}_{\mathrm{T}}\right)$ and ferric iron $\left(\mathrm{Fe}^{3+}\right)$ contents than the associated reduced samples (table 1; fig $12 \mathrm{~A}$ ). The $\mathrm{Fe}_{\mathrm{T}}$ contents in the fine-grained gray to black facies range from 1.13 to 3.76 wt.\% with the average of 2.19 wt.\% ( $\mathrm{n}=14), 1.98$ to 4.67 wt.\% with the average of 2.85 wt.\% $(n=7)$ in fine-grained green facies, and 2.04 to 9.85 wt.\% with the average of 4.47 wt.\% $(n=16)$ in fine-grained red facies. $\mathrm{Fe}^{3+} / \mathrm{Fe}_{\mathrm{T}}$ are slightly higher in the fine-grained red facies, ranging from 0.75 to 1.00 with the average of $0.91(n=16)$ than in the green facies that have ratios ranging from 0.71 to 0.92 with the average of 0.72 , except for two red facies samples (GR15-50.9 and GR25194.25) with ratios less than 0.5 (table 1; fig 12A). Remarkably, most of the fine-grained, green facies are more enriched in $\mathrm{Fe}^{3+}$ than in $\mathrm{Fe}^{2+}$, which is unusual for reduced sediments that should be enriched in $\mathrm{Fe}^{2+}$ due to redox control. Similarly, fine-grained samples with both oxidized and reduced components (figs. 5D, 5F, and $5 \mathrm{H}$ ) have generally invariable $\mathrm{Fe}^{2+}$ content, while $\mathrm{Fe}^{3+}$ content is systematically higher in red components. 
In contrast, the granular samples have much lower $\mathrm{Fe}_{\mathrm{T}}$ contents compared to the fine-

442 grained samples (fig. 12A). The granular red facies have $\mathrm{Fe}_{\mathrm{T}}$ content ranging from 0.16 to 4431.43 wt. $\%$ with the average of 0.51 wt. $\%(n=6)$ and $\mathrm{Fe}^{3+} / \mathrm{Fe}_{\mathrm{T}}$ ratios ranging from 0.1 to 0.89 with the average of $0.63(\mathrm{n}=6)$. The granular green facies contain 0.16 to 4.77 wt. $\% \mathrm{Fe}_{\mathrm{T}}$ with the average of 1.02 wt.\% $(n=3)$, whereas the granular bleached facies has a near-zero $\mathrm{Fe}_{\mathrm{T}}$ content (0.04 wt.\%; fig. 12). Variations in major elements (including Fe) are mainly due to "dilution" with detrital quartz and other non-ferric minerals (fig. 10). Hence, samples might contain hematite, while being depleted relative to the average continental crust due to this "dilution" effect. Overall, only three fine-grained red facies samples (GR15-250.3, GR15295.8, and GR15-825.75) have higher than the average continental crust $\mathrm{Fe}_{\mathrm{T}}$ content $\left(\mathrm{Fe}_{\mathrm{T}}=\right.$ 6.71 wt.\%; Rudnick and Gao, 2004; fig 12A and B).

Selected samples analyzed for Fe isotope composition are fine-grained red and green facies that have considerable $\mathrm{Fe}_{\mathrm{T}}$ content and wide range of $\mathrm{Fe} / \mathrm{Al}$ and $\mathrm{Fe} / \mathrm{Mg}$. In addition, some granular red facies samples were also analyzed. With the exception of three samples (GR15-825.75, GR15-282, and GR15-312.8), Fe isotope composition of all the samples, have high $\delta^{56} \mathrm{Fe}$ values relative to the bulk silicate Earth, which is estimated at $0.00 \pm 0.05 \%$ (for example, Beard and others, 2003b; Beard and Johnson, 2004a; Teng and others, 2013; Barrat and others, 2015; table 1 and table 2; fig. 12B). The fine-grained green samples display variable but positive bulk sample $\delta^{56} \mathrm{Fe}$ values, ranging from $+0.16 \%$ to $+0.98 \%$ with the average of $+0.44 \%$. The fine-grained red samples also have predominantly positive $\delta^{56} \mathrm{Fe}$ values, ranging from $+0.11 \%$ to $+0.80 \%$ with the average of $+0.36 \%$ except for one $\mathrm{Fe}_{\mathrm{T}}$ enriched sample (GR15-825.75) with lower $\delta^{56} \mathrm{Fe}$ value of $-0.03 \%$ (fig 12B; table 1). In contrast, granular red samples have much lower near-to-crustal $\delta^{56} \mathrm{Fe}$ values, ranging between $-0.23 \%$ and $+0.19 \%$ with the average of $0.03 \%$. There is no significant correlation between $\mathrm{Fe}$ content and $\mathrm{Fe}$ isotope composition in fine-grained green and granular red samples, whereas fine-grained red samples show weak negative correlation (fig. 12B). Similarly, $\delta^{56} \mathrm{Fe}$ 
composition is unrelated to sediment color, but appears to depend on sediment grain size. The $\delta^{56} \mathrm{Fe}$ and $\mathrm{Fe}_{\mathrm{T}}$ values are considerably higher in most of the fine-grained red and green samples compared to granular red samples (fig 12B). Overall, the $\sim 1.0 \%$ range of $\delta^{56} \mathrm{Fe}$ values in the fine-grained samples is surprisingly large compared to clastic sediments that generally show $\delta^{56} \mathrm{Fe}$ values similar to bulk silicate Earth (for example, Rouxel and others, 2003; Beard and others, 2003b; Beard and Johnson, 2004a; Severmann and others, 2006).

\section{DISCUSSION}

\section{Origin and Time of Hematite Formation in FA Formation Red beds}

Three main models have been discussed by Turner (1980) and Mucke (1994) to explain the origin of hematite pigments in continental red beds. These are: (1) primary origin through the erosion and redeposition of lateritic soils (Krynine, 1950) and dehydration of ferric hydroxides (Van Houten, 1961); (2) intrastratal alteration and ultimately dissolution of ferromagnesian silicates during burial diagenesis on contact with oxygenated water (Walker, 1967; Walker and others, 1978); and (3) secondary (late-stage) origin through surface weathering, erosion, and uplift of drab strata (Mucke, 1994). The first model favors detrital origin of hematite and sediments were already red when they were deposited, whereas models 2 and 3 support formation of hematite after deposition and sediments were not originally red when they were deposited. Hence, deciphering the time and mechanism of hematite formation is essential to discriminate between these models.

The time of hematite formation can be best constrained relative to the period of sediment deposition by establishing hematite relationship with detrital and authigenic mineral phases. Interpretation of our petrographic data suggest that hematite pigmentation in the FA Formation red beds formed through early diagenetic processes as discussed below. The earliest recorded hematite pigmentation involves partial reddening of the deltaic and tidaldeltaic lithofacies by the formation of poorly developed thin hematite rims on detrital grains. 
Presence of hematite between detrital quartz and authigenic quartz overgrowths and at points of grain contact (figs. 6E and $6 \mathrm{~F}$ ) illustrates that iron oxide precipitation via interaction with oxidized fluids in the tidal-deltaic lithofacies likely occurred before authigenic quartz overgrowths formed during early burial. The hematite rims could have formed from $\mathrm{Fe}$ derived from dissolution or alteration of unstable iron-bearing silicates and oxides or from infiltration of oxidized meteoric water during burial (Walker, 1967; Judd and others, 1970; Turner, 1980).

The quartz overgrowths, occasionally in optical continuity with the detrital host, uncommonly preserve early hematite coatings (fig. 6F). Eriksson and Cheney (1992) cautioned that presence of hematite coatings on grains is not sufficient to constrain redox conditions before or during deposition. For example, grain-coating hematite could form during transportation before sediment deposition or by infiltration of oxidized fluids after deposition. However, the rarity of hematite at grain contacts and as coatings coupled with absence of features, such as abraded quartz cement, that would protect hematite during transportation suggest that they were not surface phenomenon, but occurred long after sediment deposition. The presence of hematite on grain surfaces and on other authigenic cements (anhydrite, calcite, and clays) and in pore spaces (fig. 6F) demonstrates protracted precipitation of hematite during diagenesis, and this suggests long-lasted, oxidizing nature of migrating fluids during burial. This means that hematite likely precipitated after the influx of oxidized meteoric water that dissolves the calcite, sulphates (gypsum and anhydrite), and clay (chlorite and illite) cements during burial diagenesis.

On the other hand, absence of pore-filling, pore-lining, and grain-rimming hematite on detrital grains and at points of grain contact in the red lower fluvial lithofacies might suggest total absence of hematite coatings during deposition or dissolution during deeper burial. Reddening in the lower fluvial lithofacies is thus thought to be exclusively diagenetic in origin likely related to hematite replacement of detrital iron-rich silicate precursor during 
alteration. Evidence for later hematite replacement is best preserved in altered iron-bearing detrital grains, predominantly biotite and, rarely, ilmenite (figs. 6A, 6B, and 6C) in all the red samples. Iron and titanium may have been liberated from biotite during diagenesis, which could have promoted precipitation of leucoxene and hematite along cleavage planes. Similarly, the pseudomorphic trellis texture preserved in a few samples suggests alteration of ilmenite into leucoxene and hematite (fig. 6C). These observations provide strong evidences for in situ replacement of original precursor minerals (biotite and ilmenite) by hematite during alteration. Replacement could have involved intrastratal dissolution of iron silicate minerals by circulating oxidized fluids or infiltration of surface water and subsequent precipitation of hematite during diagenesis. This is consistent with models 2 and 3 suggesting that authigenesis of hematite took place after sedimentation and continued into late burial diagenesis.

Presence of hematite and Fe-deficient chlorite in the granular red-colored tidal-deltaic lithofacies could have resulted from interstitial oxidation of $\mathrm{Fe}^{2+}$ in $\mathrm{Fe}$-chlorite with precipitation of hematite due to influx of oxidized meteoric waters during the later oxidation event (fig. 7). This interpretation is favored by the presence of Fe-rich chlorite in most of the fine-grained red facies compared with Mg-enriched chlorite in the granular red facies (fig. 9). Furthermore, the difference between the chemistry of chlorites in fine-grained red facies where $\mathrm{Fe}$ is retained and granular red facies (fig. 7) might be due to their permeability difference. In this manner, the late, migrating oxidized fluids would have been restricted in low-permeability fine-grained sediments where sharp redox (red to green) boundaries are often observed within the deltaic lithofacies.

In addition to hematite, pore-filling and replacive carbonates, which are mainly calcite in the granular red-colored sandstones, formed during early diagenesis. The calcite is typically non-ferroan, since iron in ferric state does not easily incorporate into carbonate mineral structure. Pore-filling (fig. 6G) and grain-replacing pyrite precipitated at reduction fronts, in 
545 what are now the reduced facies. No further diagenetic minerals or changes are found

546 following pyrite precipitation.

547

548

549

550

551

552

553

554

555

556

557

558

559

560

561

562

563

564

565

566

567

568

569

570

\section{Paleo-redox Conditions Recorded by FA Formation Sediments}

Unlike sandstones, fine-grained sediments are less affected by alteration processes due to their low permeability to post-depositional fluids. The geochemical and isotopic composition of these sediments may thus help to constrain paleo-redox condition during deposition of the Paleoproterozoic FA Formation. Fe isotopes have been extensively used to trace biogeochemical redox cycling of $\mathrm{Fe}$ in modern sedimentary rocks and pore fluids because of significant $\mathrm{Fe}$ isotope fractionations that result from redox fluctuations (for example, Yamaguchi and others, 2005; Severmann and others, 2006 and 2010; Homoky and others, 2009; Rouxel and others, 2008a; Li and others, 2013a). Fe isotope analysis is particularly useful for these studies since minerals containing $\mathrm{Fe}^{3+}$ tend to have high $\delta^{56} \mathrm{Fe}$ values, while minerals bearing $\mathrm{Fe}^{2+}$ tends to have low $\delta^{56} \mathrm{Fe}$ values. Application of $\mathrm{Fe}$ isotope systematics to constrain biogeochemical processes relies on large fractionation $(\sim 3 \%$ o $)$ of $\mathrm{Fe}$ isotopes during both biotic and abiotic Fe oxidation and reduction (Beard and others, 1999; Welch and others, 2003; Croal and others, 2004; Johnson and others, 2005; Wu and others, 2011). Although identifying robust biosignature in ancient sedimentary rocks remains highly controversial due to the difficulty to distinguish biotic from abiotic processes (Johnson and others, 2005; Craddock and Dauphas, 2011; Guilbaud and others, 2011), Fe isotopes in iron formations and black shales have been used extensively to constrain ancient ocean redox conditions and Fe cycling in the oceans (Rouxel and others, 2005; Bekker and others, 2010; Planavsky and others, 2012; Moeller and others, 2014).

Generally, Fe content and Fe isotope composition of sedimentary rocks are primarily controlled by syn- to post-depositional processes that remove or add Fe resulting in a combination of detrital and diagenetic minerals with distinct $\mathrm{Fe}$ isotope compositions. Fe 
572 Fe/Ti (Werne and others, 2002) and Fe/Al (Lyons and others, 2003), provided that the

573 lithogenic end-member is similar to the average continental crust. In clastic sedimentary rocks, major element composition is essentially controlled by the relative abundances of

minerals such as quartz (diluting other constituents with $\mathrm{SiO}_{2}$ ), rock fragments, and a range of Al- and Fe-Mg-silicates such as feldspar and clay minerals. As illustrated in figure $10, \mathrm{~K}_{2} \mathrm{O}$, $\mathrm{Al}_{2} \mathrm{O}_{3}$, and $\mathrm{TiO}_{2}$ are relatively well correlated with each other, while $\mathrm{SiO}_{2}$ is unrelated to any other major element being quartz-controlled.

In organic-poor siliciclastic rocks, minerals that are responsible for bulk-rock Fe isotope composition that deviates from zero include ferric oxide/hydroxide, iron-rich carbonates, and magnetite (Beard and Johnson, 2004a). Detrital and authigenic silicates have $\delta^{56} \mathrm{Fe}$ values close to zero, resulting in Fe isotope composition of weathering products and clastic sedimentary rocks (example, oceanic turbidites, aeolian and fluvial sediments, suspended river load, loess, and aerosols) being similar to crustal values (Beard and others, 2003b; Beard and Johnson, 2004a; table 2). Since silicates and hematite are the main Febearing minerals in the studied samples, we plotted $\left(\mathrm{K}_{2} \mathrm{O}+\mathrm{Na}_{2} \mathrm{O}\right) / \mathrm{Al}_{2} \mathrm{O}_{3}$ versus $\mathrm{Fe}_{2} \mathrm{O}_{3 \mathrm{~T}} /\left(\mathrm{Fe}_{2} \mathrm{O}_{3 \mathrm{~T}}+\mathrm{MgO}\right)$ to explore mixing between various silicate minerals and hematite. The bulk-rock compositions fall in the biotite-hematite-illite triangle field (fig. 13A). Most of the samples plotted close to the biotite-hematite mixing line suggesting that biotite (and its alteration products) and iron oxides (hematite) are the principal mineral hosts for $\mathrm{Fe}$; however, contribution from chlorite cannot be excluded. Moderate correlation between Fe/Mg and $\delta^{56} \mathrm{Fe}$ values in all samples $\left(\mathrm{R}^{2}=0.6\right.$; fig. 13B) suggests that positive Fe isotope values are related to hematite addition (resulting in increase of $\mathrm{Fe} / \mathrm{Mg}$ ), while low $\mathrm{Fe} / \mathrm{Mg}$ and $\delta^{56} \mathrm{Fe}$ values reflect silicate abundance. The fact that $\delta^{56} \mathrm{Fe}$ values and $\mathrm{Fe} / \mathrm{Mg}$ positively correlate clearly argues against in situ Fe (III) reduction (for example, via microbial dissimilatory reduction) that would result in a loss of isotopically light $\mathrm{Fe}$, leaving a residue enriched in 
601

602

603

604

605

606

607

608

609

610

611

612

heavy isotopes (for example, Beard and others, 2003b; Beard and Johnson, 2004a; Wu and others, 2012). In this case, Fe isotope values would produce an inverse relationship with $\mathrm{Fe} / \mathrm{Mg}$ ratios.

Overall, the range of $\delta^{56} \mathrm{Fe}$ values (table 1; figs. 12B and 13B) is very large, which is quite remarkable considering the relatively modest Fe enrichment with respect to the average crustal value (table 2); in addition, the largest range in $\delta^{56} \mathrm{Fe}$ values is in the fine-grained samples. The range of positive values, up to 1 per mil, is similar to that found in Paleoproterozoic and Archean iron formations (for example, Bekker and others, 2010, 2014; Planavsky and others, 2012), suggesting partial Fe oxidation under mildly oxidizing conditions during early diagenesis resulting in origin of red beds. Then hematite precipitates under highly oxidizing conditions and neutral $\mathrm{pH}$, it is expected that $\mathrm{Fe}$ (II) oxidation would be quantitative (for example, Kuma and others, 1996), resulting in $\delta^{56} \mathrm{Fe}$ values of the precipitate being similar to that of initial Fe (II) in water column that is probably near or below the average continental crust value. Therefore, the high $\delta^{56} \mathrm{Fe}$ values are not consistent with iron oxyhydroxide precipitation under strongly oxidized conditions, but rather with partial oxidation of Fe (II) under mildly oxidized conditions. Small range in $\delta^{56} \mathrm{Fe}$ values for the granular red facies (table 1 and figs. 12B and 13B) with a mean value of $0.03 \%$ suggests Fe-derivation from crustal alteration.

Another evidence for mildly oxidizing conditions during deposition of the FA Formation is that $\mathrm{Cr}$ enrichment when normalized to $\mathrm{Fe}(\mathrm{Cr} / \mathrm{Fe})$ shows good correlation with $\delta^{56} \mathrm{Fe}$ values, especially for the fine-grained sediments $\left(\mathrm{R}^{2}=0.95\right.$ for the red facies of the finegrained sediments without one outlier; fig. 14). This is a strong evidence for authigenic $\mathrm{Cr}$ enrichment, where $\mathrm{Cr}$ is mobilized as $\mathrm{Cr}$ (VI) in weathering surficial environments under strongly oxidizing conditions (Frei and others, 2009; Konhauser and others, 2011) and is scavenged when $\mathrm{Fe}$ (II) oxidized at a redoxcline leading to the precipitation of iron oxyhydroxides with heavy $\mathrm{Fe}$ isotope values and $\mathrm{Cr}$ enrichment. 
624

625

626

627 green samples (figs. 12A and 15), and they both display variability in $\mathrm{Fe}^{3+} / \mathrm{Fe}_{\mathrm{T}}$ that indicates redox-induced $\mathrm{Fe}$ mobility. It is clear that the reduced green facies with lower $\mathrm{Fe}^{3+} / \mathrm{Fe}_{\mathrm{T}}$ ratios have similar positive $\delta^{56} \mathrm{Fe}$ values to the oxidized red facies (fig. 16), suggesting that $\delta^{56} \mathrm{Fe}$ values are unrelated to $\mathrm{Fe}^{3+} / \mathrm{Fe}_{\mathrm{T}}$ and color, albeit being the result of partial $\mathrm{Fe}$ oxidation. This strongly suggests that isotopically heavy hematite or its precursor with ${ }^{56} \mathrm{Fe}$-enriched $\mathrm{Fe}^{3+}$ were initially present and conserved in some cases, and the green facies likely formed later by replacement of the red facies under more reducing intrastratal conditions. Under these conditions, newly formed clay minerals of the green facies (illite and chlorite) would retain the initial (heavy) Fe isotope composition of the protolith/precursor. Reducing conditions are expected to develop during diagenesis in basinal fluids and may lead to Fe mobility. Fe concentrations and $\mathrm{Fe} / \mathrm{Mg}$ ratios (fig. 13B) however suggest that loss of $\mathrm{Fe}$ was moderate and did not result in significant depletion in light $\mathrm{Fe}$ isotopes through their preferential release with $\mathrm{Fe}^{2+}$. Replacement of the green facies with the red facies does not seem plausible since late-stage oxidation, for instance through circulation of oxidizing fluids, would not generate positive $\delta^{56} \mathrm{Fe}$ values considering that $\mathrm{Fe}$ would be quantitatively immobilized during this fluid-rock interaction in an oxygenated environment. Low mobility of $\mathrm{Fe}^{3+}$ and conservative behavior of $\mathrm{Fe}$ during this process would result in preservation of the original $\mathrm{Fe}$ isotope composition (Beard and others, 2003b; Beard and Johnson, 2004a). Preservation of heavy Fe isotope values relative to the average continental crust, which was interpreted as a signature of partial $\mathrm{Fe}^{2+}$-oxidation, has also been observed in the Early Archean rocks such as jaspers, BIF, and ferruginous schists (Dauphas and others, 2004; Yamaguchi and others, 2005; Czaja and others, 2013; Li and others, 2013a). 
649 FA Formation of the Franceville Basin have been discussed by Gauthier-Lafaye (1986), 650 Gauthier-Lafaye and Weber (2003) and Gauthier-Lafaye (2006). These studies emphasized 651 the rise of atmospheric oxygen during the GOE, leaching of U-bearing conglomeratic 652 sandstones in the lower fluvial sandstones and upward U-mobilization by oxidized basinal 653 fluids along faults, fractures, and zones of permeability, and precipitation of the liberated U in 654 the upper part of the FA Formation when basinal fluids interacted with reduced fluids bearing

655

656

657

658

659

660

661

662

663

664

665

666

667 hydrocarbons that were derived from the FB Formation.

Our geochemical data tend to provide clue on the source of $U$ in the basin. Uranium and thorium contents in nearly all lithofacies and diagenetic facies reflect the amount present in the original detrital material based on the small range of the U/Th ratios irrespective of the oxidation state and lithology (fig. 11). Although the source for U mineralization remains to be unconstrained (either Archean basement or basal oxidized sandstones), its precipitation at the interface with the reduced sediments furnished $U$ mineralization in the oldest known sandstone-hosted deposit in the FA Formation of the Franceville Basin. Heterogeneous distribution of $U$ likely reflects further constraints by the structural evolution of the basin in controlling fluid pathways leading to the mineralization process. The model requires an oxygenated atmosphere and a recharge area for the leaching oxidized fluids. Thus, a welloxygenated atmosphere is required during the mineralization at ca. $2.0 \mathrm{Ga}$ (ca. $0.35 \mathrm{Ga}$ after the GOE; Bekker and others, 2004), the suggested age of U mobilization in the Franceville Basin. The recharge zone for the oxidized fluids in the Franceville Basin might have developed during basin inversion, at the late burial stage of the Franceville Series, to the northwest of the basin in the mobile orogenic belt of Ogooué (Gauthier-Lafaye and Weber, 1989). 
The FA Formation consists of immature siliciclastic sediments of fluvial, deltaic, and tidal-

675

deltaic origin. The lower fluvial sandstones and conglomerates in the central part of the basin are mostly reddish-pink (oxidized), while the middle to upper parts consist of alternation of reduced, drab (green, gray, and black) and red, medium- to fine-grained sandstones and interbedded mudstones. Petrographic evidence shows that ferric oxides are dispersed in clay filling intergranular pores and developed along platy cleavage in altered phyllosilicates. Based on the rare presence of hematite as grain coatings and at grain contacts, and on surfaces of authigenic cements, we infer that hematite precipitation probably started after sediment deposition and continued during burial diagenesis. Iron was likely supplied internally by alteration of iron-bearing minerals (predominantly biotite) within the sediments and redistributed in rocks during late diagenesis under mildly oxidized conditions, but an external source cannot be totally excluded. The drab color formed much later in contact with reduced basinal fluids.

$\mathrm{U}$ mineralization formed at the reduction front when oxidized basinal fluids, which circulated along faults, fractures, and zones of permeability, interacted with migrating hydrocarbons derived from the overlying organic matter-rich FB Formation during basin inversion. Circulation of oxidized, basinal fluids likely led to the loss of uranium from the basal, fluvial oxidized sandstones and its enrichment in the reduced sandstone and silty mudstone in the upper, tidal-deltaic sediments, generating uranium mineralization of the oldest known sandstone-type deposit in the Paleoproterozoic FA Formation of the Franceville Basin.

\section{ACKNOWLEDGEMENTS}

The authors wish to acknowledge CNRS-INSU, FEDER, the University of Poitiers, and Région Poitou-Charente for financial support and Gabon Ministry of Education and Research, CENAREST, Gabon Ministry of Mines, Oil, Energy and Hydraulic Resources, 
General Direction of Mines and Geology, Agence Nationale des Parcs Nationaux of Gabon,

COMILOG, and French Embassy at Libreville for collaboration and technical support. A.B. acknowledges support from NSF grant EAR-05-45484, NASA Astrobiology Institute Award NNA04CC09A, and an NSERC Discovery and Accelerator Grants. For laboratory and other assistance, we acknowledge F. Weber, L. Ngombi Pemba, I. Moubiya-Mouélé, N. Ononga, C. Fontaine, C. Laforest, and N. Dauger. Careful reviews by Kevin Ansdell and Axel Hofmann helped tremendously to improve this article.

\section{APPENDICES}

Figure A-1 Photomicrographs of hematite: (A-B) postdating calcite and anhydrite cements in tidal-deltaic lithofacies; (C-D replacing muscovite along cleavage in the lower fluvial lithofacies.

Table A-1 Chemical composition of authigenic chlorite in the red and green facies of the FA Formation (structural formula was calculated based on 14 oxygen atoms)

Table A-2 Geochemical composition of the red beds, FA Formation, Franceville Basin, Gabon

\section{REFERENCES}

Azzibrouck-Azziley, G., ms, 1986, Sédimentologie et géochimie du Francevillien B (Protérozoïque inférieur), in: Métallogénie des gisements de manganèse de Moanda, Gabon: PhD. thesis, Université Louis Pasteur, Strasbourg, 210 p.

Bankole, O.M., El Albani, A., Meunier, A., Gauthier-Lafaye, F., 2015, Textural and paleofluid flow control on diagenesis in the Paleoproterozoic Franceville Basin, South Eastern, Gabon: Precambrian Research, v. 268, p. 115-134.

Bankole, O.M., ms, 2015, Transformation diagenetiques des depots silicoclastiques fa du bassin de franceville au Gabon (2.2-2.0 ga) par l'invasion de solution oxydoreductrices: $\mathrm{PhD}$. thesis, Université de Poitiers, $199 \mathrm{p}$.

Barrat, J.A., Rouxel, O., Wang, K., Moynier, F., Yamaguchi, A., Bischoff, A., and Langlade, J., 2015, Early stages of core segregation recorded by Fe isotopes in an asteroidal 
mantle: Earth and Planetary Science Letters, v. 419, p. 93-100.

Beard, B.L., Johnson, C.M., Cox, L., Sun, H., Nealson, K.H., and Aguilar, C., 1999, Iron Isotope Biosignatures: Science, v. 285, p. 1889-1892.

Beard, B.L., Johnson, C.M., Von Damm, K.L., and Poulson, R.L., 2003a, Iron isotope constraints on Fe cycling and mass balance in oxygenated Earth oceans: Geology, v. 31, p. 629-632.

Beard B. L., Johnson C. M., Skulan J. L., Nealson K. H., Cox L., and Sun H., 2003b, Application of $\mathrm{Fe}$ isotopes to tracing the geochemical and biological cycling of Fe: Chemical Geology, v. 195, p. 87-117.

Beard, B.L., and Johnson, C.M., 2004a, Fe isotope variations in the modern and ancient Earth and other planetary bodies: Reviews in Mineralogy \& Geochemistry, v. 55, p. 319357.

Bekker, A., Holland, H.D., Wang, P.L., Rumble III, D., Stein, H.J., Hannah, J.L., Coetzee, L.L., and Beukes, N.J., 2004, Dating the rise of atmospheric oxygen: Nature, v. 427, p. 117-120.

Bekker, A., Slack, J.F., Planavsky, N., Krapez, B., Hofmann, A., Konhauser, K.O., and Rouxel, O.J., 2010, Iron Formation: The sedimentary product of a complex interplay among mantle, tectonic, oceanic, and biospheric processes: Economic Geology, v. 105, p. 467-508.

Bekker, A., and Holland, H.D., 2012, Oxygen overshoot and recovery during the early Paleoproterozoic: Earth and Planetary Science Letters, v. 317-318, p. 295-304.

Bekker, A., Planavsky, N., Rasmussen, B., Krapez, B., Hofmann, A., Slack, J., Rouxel, O., and Konhauser, K., 2014, Iron Formations: Their Origins and Implications for Ancient Seawater Chemistry, in Holland, H., and Turekian, K., editors, Treatise on Geochemistry: Elsevier-Netherland, v. 2, p. 561-628.

Bonhomme, M.G., Gauthier-Lafaye, F., and Weber, F., 1982, An example of lower Proterozoic sediments: The Franceville in Gabon: Precambrian Research, v. 18, p. 87102.

Bros, R., Stille, P., Gauthier-Lafaye, F., Weber, F., and Clauer, N., 1992. Sm-Nd isotopic dating of Proterozoic clay material: An example from the Franceville sedimentary series, Gabon: Earth and Planetary Science Letters, v. 113, p. 207-218.

Bullen, T.D., White, A.F., Childs, C.W., Vivit, D.V., and Schulz, M.S., 2001, Demonstration of significant abiotic iron isotope fractionation in nature: Geology, v. 29, p. 699-702.

Chandler, F.W., 1980, Proterozoic red bed sequences of Canada: Geological Survey Bulletin 
311, 62p.

Cortial, F., Gauthier-Lafaye, F., Lacrampecouloume, G., Oberlin, A., and Weber, F., 1990, Characterization of organic matter associated with uranium deposits in the Franceville Formation of Gabon (Lower Proterozoic): Organic Geochemistry, v. 15, p. 73-85.

Craddock, P.R., and Dauphas, N., 2011, Iron isotopic compositions of geological reference materials and chondrites: Geostandards and Geoanalytical Research, v. 35, p. 101-123.

Croal, L.R., Johnson, C.M., Beard, B.L., and Newman, D.K., 2004, Iron isotope fractionation by $\mathrm{Fe}(\mathrm{II})$-oxidizing photoautotrophic bacteria: Geochimica et Cosmochimica Acta, v. 68, p. 1227-1242.

Cuney, M. and Mathieu, R., 2000, Extreme light rare earth mobilization by diagenetic fluids in the geological environment of the Oklo natural reactor zones, Franceville basin, Gabon: Geology, v. 28, p. 743-746.

Cuney, M., 2010, Evolution of uranium fractionation processes through time: driving the secular variation of uranium deposit types: Economic Geology, v. 105, p. 553-569.

Czaja, A.D., Johnson, C.M., Beard, B.L., Roden, E.E., Li, W., and Moorbath, S., 2013, Biological Fe oxidation controlled deposition of banded iron formation in the ca. 3770 Ma Isua Supracrustal Belt (West Greenland): Earth and Planetary Science Letters, v. 363, p. 192-203.

Dauphas, N., VanZuilen, M., Wadhwa, M., Davis, A.M., Marty, B., and Janney, P.E., 2004, Clues from $\mathrm{Fe}$ isotope variations on the origin of early Archean BIFs from Greenland: Science, v. 306, p. 2077-2080.

Dutkiewicz, A., George, S.C., Mossman, D.J., Ridley J., and Volk, H., 2007, Oil and its biomarkers associated with the Palaeoproterozoic Oklo natural fission reactors, Gabon: Chemical Geology, v. 244, p. 130-154.

El Albani A. A., Stefan B., Donald E. C., Armelle R., Claire R. B., Roberto M, Lauriss N. P., Emma H., Alain M., Idalina M. M., Karim B., Sylvain B., Philippe B., Marc C., Christian C., Claude F., Ernest C. F, Juan M. G. R., Francois G. L., Arnaud M., Anne C. P. W., Olivier R., Alain T., Marco V., Gerard J. M., Lee W., Martin W., and Andrey B., 2014, The 2.1 Ga Old Franceville biota: biogenicity, Taphonomy, and biodiversity: PLoS-ONE, 9(6): e99438. doi:10.1371/journal.pone.0099438

Eriksson, P.G., and Cheney, E.S., 1992, Evidence for the transition to an oxygen-rich atmosphere during the evolution of red beds in the Lower Proterozoic sequences of southern Africa: Precambrian Research, v. 54, p. 257-269. 
Feybesse, J.L., Johana, V., Triboulet, C., Guerrota, C., Mayaga-Mikoloc, F., Bouchota, V., and Eko N'dong J., 1998, The West Central African belt: a model of 2.5-2.0 Ga accretion and two-phase orogenic evolution: Precambrian Research, v. 87, p. 161-216.

Frei, R., Gaucher, C., Poulton, S.W., and Canfield, D.E., 2009, Fluctuations in Precambrian atmospheric oxygenation recorded by chromium isotopes: Nature, v. 461, p. 250-253.

Gancarz, A.J., 1978, U-Pb age (2.05 x $10^{9}$ years) of the Oklo uranium deposit, in GauthierLafaye, F., Time constraint for the occurrence of uranium deposits and natural nuclear fission reactors in the Paleoproterozoic Franceville Basin (Gabon): Geological Society of America, v. 198, p. 157-167.

Gauthier-Lafaye, F., ms, 1986, Les gisements d'uranium du Gabon et les reacteurs d'Oklo. Modèle métallogénique de gîtes à fortes teneurs du protérozoique inférieur: $\mathrm{PhD}$. thesis, Université de Strasbourg, France, 206 p.

Gauthier-Lafaye, F., and Webber, F., 1989, The Franceville (Lower Protérozoic) Uranium ore deposits of Gabon: Economic Geology, v. 84, p. 2267-2285.

Gauthier-Lafaye F., and Weber F., 2003, Natural nuclear fission reactors: time constraints for occurrence, and their relation to uranium and manganese deposits and to the evolution of the atmosphere: Precambrian Research, v. 120, p. 81-100.

Gauthier-Lafaye, F., 2006, Time constraint for the occurrence of uranium deposits and natural nuclear fission reactors in the Paleoproterozoic Franceville Basin (Gabon): Geological Society of America, v. 198, p. 157-167.

Guilbaud, R., Butler, I.B., and Ellam, R.M., 2011, Abiotic Pyrite Formation Produces a Large Fe Isotope Fractionation: Science, v. 332, p. 1548-1551.

Haubensack, C., ms, 1981, Environnement des grès protérozoïques et des indices uranifères du secteur Kiéné dans le bassin de Franceville (République Gabonaise): aspects sédimentologiques et géochimiques: PhD. thesis, Université de Strasbourg, France, $109 \mathrm{p}$.

Holland, H.D., 2002, Volcanic gases, black smokers, and the great oxidation event: Geochemica et Cosmochimica Acta, v. 66, p. 3811-3826

Holliger, P., 1988, Ages U-Pb definis in-situ sur oxydes d'uranium a l'analyseur ionique: Methodologie et consequences géochimiques, in Gauthier-Lafaye, F., Time constraint for the occurrence of uranium deposits and natural nuclear fission reactors in the Paleoproterozoic Franceville Basin (Gabon): Geological Society of America, v. 198, p. $157-167$.

Homoky, W.B., Severmann, S., Mills, R.A., Statham, P.J., and Fones, G.R. 2009, Pore-fluid 
Fe isotopes reflect the extent of benthic Fe redox recycling: Evidence from continental shelf and deep-sea sediments: Geology, v. 37, p. 751-754.

Johnson, C.M., Skulan, J.L., Beard, B.L., Sun, H., Nealson, K.H., and Braterman, P.S., 2002, Isotopic fractionation between $\mathrm{Fe}(\mathrm{III})$ and $\mathrm{Fe}(\mathrm{II})$ in aqueous solutions: Earth and Planetary Science Letters, v. 195, p. 141-153.

Johnson, C.M., Roden, E.E., Welch, S.A., and Beard, B.L., 2005, Experimental constraints on $\mathrm{Fe}$ isotope fractionation during magnetite and Fe carbonate formation coupled to dissimilatory hydrous ferric oxide reduction: Geochemica et Cosmochimica Acta, v. 69, p. 963-993.

Judd, J.B., Smith, W.C., and Pilkey, O.H., 1970, The environmental significance of ironstained quartz grains on the southeastern United States Atlantic shelf: Marine geology, v. 8 , p. 355-362.

Konhauser, K.O., Lalonde, S.V., Planavsky, N.J., Pecoits, E., Lyons, T.W., Mojzsis, S.J., Rouxel, O.J., Barley, M.E., Phillop, C.R., Fralick, W., Kump, L.P., and Bekker, A., 2011, Aerobic bacterial pyrite oxidation and acid rock drainage during the Great Oxidation Event: Nature, v. 478, p. 369-373.

Krynine, P.D., 1950, The Origin of red beds, in Turner, P., Continental red beds, Development in Sedimentology: Elsevier, v. 29, 577p.

Kuma, K., Nishioka J., and Matsunaga, K., 1996, Controls on iron (III) hydroxide solubility in seawater: the influence of $\mathrm{pH}$ and natural organic chelators: Limnology and Oceanography, v. 41, p. 396-407.

Li, W., Czaja, A.D., Van Kranendonk, M.J., Beard, B.L., Roden, E.E., and Johnson, C.M., 2013a, An anoxic, Fe(II)-rich, U-poor ocean 3.46 billion year ago. Geochimica et Cosmochimica Acta, v. 120, p. 65-79.

Lyons, T.W., Werne, J.P., Hollander, D.J., and Murray, J.W., 2003, Contrasting sulphur geochemistry and $\mathrm{Fe} / \mathrm{Al}$ and $\mathrm{Mo} / \mathrm{Al}$ ratios across the last oxic-to-anoxic transition in the Cariaco Basin, Venezuela: Chemical Geology, v. 195, p. 131-157.

Mathieu, R., Cuney, M., and Cathelineau, M., 2000, Geochemistry of palaeofluids circulation in the Franceville basin and around Oklo natural nuclear reaction zones (Gabon): Journal of Geochemical Exploration, v. 69, p. 245-249.

Mathieu, R., Zetterstrom, L., Cuney, M., Gauthier-Lafaye, F., and Hidaka, H., 2001, Alteration of monazite and zircon and lead migration as geochemical tracers of fluid paleocirculations around the Oklo-Okèlobondo and Bangombé natural nuclear reaction zones, Franceville Basin, Gabon: Chemical Geology, v. 171, p. 147-171. 
Metcalfe, R., Rochelle, C.A., Savage, D., and Higgo, J.W., 1994, Fluid-rock interactions during continental red bed diagenesis: implications for theoretical models of mineralization in sedimentary basins, in: Parnell, J., editor, Geofluids: Origin, Migration and Evolution of Fluids in Sedimentary Basins: Geological Society Special Publication No. 78, p. 301-324.

Moeller, K., Schoenberg, R., Grenne, T., Thorseth, I.H., Drost, K., and Pedersen, R.B. 2014, Comparison of iron isotope variations in modern and Ordovician siliceous $\mathrm{Fe}$ oxyhydroxide deposits: Geochimica et Cosmochimica Acta, v. 126, p. 422-440.

Moore, D.M., and Reynolds, R. C. Jr., 1997, X - Ray Diffraction and the identification and analysis of clay minerals: Oxford University Press, edition 2, 378p.

Mossman, D.J., 2001, Hydrocarbon habitat of Paleoproterozoic Franceville Series, Republic of Gabon: Energy Sources, v. 23, p. 45-53.

Mossman, D.J., Gauthier-Lafaye, F., Simon, E.J., 2005, Black shales, organic matter, ore genesis and hydrocarbon generation in the Paleoproterozoic Franceville Series, Gabon. Precambrian Research, v. 137, p. 253-272.

Mucke, A., 1994, Part 1: Postdiagenetic ferruginization of sedimentary rocks (sandstones, oolitic ironstones, kaolins, and bauxites)-including a comparative study of the reddening of red beds, in: Wolf, K.H., and Chilingarian, G.V., editors, Diagenesis IV, Developments in Sedimentology: Elsevier, v. 51, p. 361-395.

Naudet, R., 1991, Oklo: Des réacteurs nucléaires fossils: Paris Collection du Commissariat à l'Energie Atomique, 695p.

Ossa Ossa F., ms, 2010, Etude multi-approches du bassin sedimentaire paleoproterozoïque (2.1-2.4 Ga) de franceville au gabon: les environnements sedimentaires et l'impact des paleocirculations de fluides: PhD. thesis, Université de Poitiers, 191 p.

Ossa Ossa, F.O., Hofmann, A., Vidal, O., Kramers, J.D., Agangi, A., Belyanin, G.A., and Mayaga-Mikolo, F., 2014, Hydrothermal clay mineral formation in the uraniferous Paleoproterozoic FA Formation, Francevillian basin, Gabon: Precambrian Research, v. 246, p. 134-149.

Pambo, F., ms, 2004, Conditions de formation des carbonates de manganese Proterozoiques et analyse mineralogy et geochimigues des minerals a bioxydes de manganese associes dans le gisement de Moanda, Sud-Est, Gabon: PhD. thesis, Université de Strasbourg, $274 \mathrm{p}$.

Planavsky, N., Rouxel, O.J., Bekker, A., Hofmann, A., Little, C.T.S., and Lyons, T.W., 2012, Iron isotope composition of some Archean and Proterozoic iron formations: 
Geochimica et Cosmochimica Acta, v. 80, p. 158-169.

Poitrasson, F., and Freydier, R., 2005, Heavy iron isotope composition of granites determined by high resolution MC-ICP-MS: Chemical Geology, v. 222, p. 132-147.

Préat, A., Bouton, P., Thiéblemont, D., Prian, J. P., Ndounze, S. S., and Delpomdor, F., 2011, Paleoproterozoic high $\delta^{13} \mathrm{C}$ dolomites from the Lastoursville and Franceville basins (SE Gabon): Stratigraphic and syn-sedimentary subsidence implications: Precambrian Research, v. 189, p. 212-228.

Rouxel, O.J., Dobbek, N., Ludden, J., and Fouquet, Y., 2003, Iron isotope fractionation during oceanic crust alteration: Chemical Geology, v. 202, p. 155-182.

Rouxel, O.J., Bekker, A., Edwards, and K.J., 2005: Iron isotopes constraints on the Archean and Paleoproterozoic ocean redox state: Science, v. 307, p. 1088-1091.

Rouxel, O.J, Sholkovitz, E., Charette, M., and Edwards, K.J., 2008a, Iron Isotope fractionation in subterranean estuaries: Geochimica et Cosmochimica Acta, v. 72, p. 3413-3430.

Rudnick, R.L., Gao, S., 2004, Composition of the Continental Crust, in: Holland, H.D. and Turekian, K.K., editors, Treatise on Geochemistry: Elsevier, Amsterdam, v. 3, p. 1-64.

Ruffenach, J.C., 1978, Etude des migrations de l'uranium et des terres rares sur une carotte de sondage et application a la determination de la date des reactions nucleaires, in Gauthier-Lafaye, F., Time constraint for the occurrence of uranium deposits and natural nuclear fission reactors in the Paleoproterozoic Franceville Basin (Gabon): Geological Society of America, v 198, p. 157-167.

Severmann, S., Johnson, C.M., Beard, B.L., and McManus, J., 2006, The effect of early diagenesis on the $\mathrm{Fe}$ isotope compositions of porewaters and authigenic minerals in continental margin sediments: Geochimica et Cosmochimica Acta, v. 70, p. 20062022.

Severmann, S., McManus, J., Berelson, W.M., and Hammond, D.E., 2010, The continental shelf benthic iron flux and its isotope composition: Geochimica et Cosmochimica Acta, v. 74, p. 3984-4004.

Sharma, M., Polizzotto, M., and Anbar, A.D., 2001, Iron isotopes in hot springs along the Juan de Fuca Ridge: Earth and Planetary Science Letters, v. 194, p. 39-51.

Teng, F.Z., Dauphas, N., Huang, S.C., and Marty, B., 2013, Iron isotopic systematics of oceanic basalts: Geochimica et Cosmochimica Acta, v. 107, p. 12-26.

Thiéblemont, P., Castaing, C., Billa, M., Bouton, P., and Préat, A., 2009, Notice explicative 
de la carte géologique et des ressources minerales de la Republique Gabonaise: BRGM-Ministere des Mines, des Hydrocarbures, Libreville, scale 1:1,000,000.

Thiéblemont, D., Boulton, P., Préat, A., Goujou, J.-C., Tegyey, M., Weber, F., Ebang Obiang, E., Joron, J.L., and Treuil, M., 2014, Transition from alkaline to calc-alkaline volcanism during evolution of the Paleoproterozoic Franceville basin of eastern Gabon (Western Central Africa): Journal of African Earth Sciences, v. 99 (b), p. 215-227.

Turner, P., 1980, Continental red beds: Development in Sedimentology, Elsevier, Netherlands, v. 29, 577p.

Walker, T.R., 1967, Formation of red beds in modern and ancient deserts: Geological Society of America Bulletin, v.78, p. 353-368.

Walker, T. R., Waugh, B., and Crone, A. J., 1978, Diagenesis in first - cycle desert alluvium of Cenozoic age, southwestern United States and northwestern Mexico, in Turner, P., Continental red beds, Development in Sedimentology, Elsevier, Netherlands, v. 29, $577 \mathrm{p}$.

Weber F., ms, 1968, Une série précambrienne du Gabon: le Francevillien, sédimentologie, géochimie, relations avec les gîtes minéraux: $\mathrm{PhD}$. thesis, Université de Strasbourg, $372 \mathrm{p}$.

Welch, S.A., Beard, B.L., Johnson, C.M., and Braterman, P.S., 2003, Kinetic and equilibrium $\mathrm{Fe}$ isotope fractionation between aqueous $\mathrm{Fe}(\mathrm{II})$ and $\mathrm{Fe}(\mathrm{III})$ : Geochimica et Cosmochimica Acta, v. 67, p. 4231-4250.

Werne, J.P., Sageman, B.B., Lyons, T.W., and Hollander, D.J., 2002, An integrated assessment of a 'type euxinic' deposit: evidence for multiple controls on black shale deposition in the Middle Devonian Oatka Greek Formation, in Raiswell, R., and Canfield, D.E., The iron biogeochemical cycle past and present, Geochemical Perspectives: European Association of Geochemistry, v. 1, 232p.

Weyer, S., and Schwieters, J.B., 2003, High precision Fe isotope measurements with high mass resolution MC-ICPMS: International Journal of Mass Spectrometry. v. 226, p. 355-368.

Wiesli, R.A., Beard, B.L., and Johnson, C.M., 2004, Experimental determination of Fe isotope fractionation between aqueous $\mathrm{Fe}(\mathrm{II})$, siderite, and green rust in abiotic system: Chemical Geology, v. 221, p. 343- 362.

Wu, L.L., Beard, B.L., Roden, E.E., and Johnson, C.M., 2011, Stable iron isotope fractionation between aqueous Fe(II) and hydrous ferric oxide: Environmental Science \& Technology, v. 45, p. 1847-1852. 
Wu L., Percak-Dennett E. M., Beard B. L., Roden E. E., and Johnson C. M., 2012, Stable iron isotope fractionation between aqueous $\mathrm{Fe}(\mathrm{II})$ and model Archean ocean $\mathrm{Fe}-\mathrm{Si}$ coprecipitates and implications for iron isotope variations in the ancient rock record: Geochimica et Cosmochimica Acta, v. 84, 14-28.

Van Houten, F.B., 1961, Climatic significance of red beds, in Origin of red beds - a review: Annual Reviews Earth Planet Science, v. 1, p. 39-61.

Van Houten, F.B., 1973, Origin of red beds - a review: Annual Reviews Earth Planet Science, v. 1, p. 39-61.

Yamaguchi K.E., Johnson, C.M., Beard, B.L., and Ohmoto, H., 2005, Biogeochemical cycling of iron in the Archean-Paleoproterozoic Earth: constraints from iron isotope variations in sedimentary rocks from the Kaapvaal and Pilbara Cratons: Chemical. Geology, v. 218, p. 135-169.

Figure captions

Fig. 1. (A) Simplified geological map of Gabon showing the Francevillian Series and the Franceville Basin (Modified after Thiéblemont and others, 2014); (B) Simplified geological and structural map of the Franceville Basin showing the locations of the drill holes used in this study (Modified after Ossa Ossa, ms, 2010).

Fig. 2. Lithostratigraphic column of the Paleoproterozoic Francevillian Series in the Franceville Basin. The focus of this study is the FA Formation. Modified after GauthierLafaye and Weber, 2003.

Fig. 3. $\mathrm{N}$ to $\mathrm{S}$ cross-section of the central part of the Franceville Basin near Kiene-Otobo (see fig. 1 for the locations of the drill holes), showing variations in sediment color within the basin. Modified from Haubensack (ms, 1981) and Gauthier-Lafaye (ms, 1986).

Fig. 4. Simplified GR 15 drill hole log based on core observations. Some of the selected samples for this study are shown in figure 5 with their sampling depths. [a: Interpretations are from Haubensack (1981) and Gauthier-Lafaye (1986)].

Fig. 5. Photographs showing examples of characteristic rock types and colors in red beds of the FA Formation: (A) massive, structureless coarse-grained red-colored sandstone (fluvial lithofacies, Zone 4); (B) massive, structureless medium- to coarse-grained white (bleached) sandstone with large quartz grains at the base (fluvial lithofacies, Zone 4); (C) cross-bedded, medium- to coarse-grained blackish sandstone (fluviodeltaic lithofacies, Zone 2); (D) massive and structureless red-green mudstone with sharp discordant redox boundary (arrows; deltaic lithofacies; Otobo Series); (E) greenish mudstone with plane laminations (deltaic lithofacies, Otobo Series); (F) fine-grained, reddish sandstone with inclined laminations (tidal-deltaic lithofacies; Zone 3); (G) silty greenish mudstone with inclined planar bedding above crossand flaserbedding (deltaic lithofacies, Otobo Series); (H) surface of a silty mudstone showing cross-cutting oxidized (red) and reduced (green) spots (deltaic lithofacies, Otobo Series). 
Fig. 6. Photomicrographs of representative samples of the FA Formation: (A) quartz wacke composed of deformed and hematized biotite (fine-grained, red tidal-deltaic lithofacies; XP); (B) quartz wacke with pore-filling hematitic pigment within illite matrix and hematized mica grain (fine-grained, red tidal-deltaic lithofacies; BSE); (C) pseudomorph of hematite after trellis ilmenite texture in quartz wacke (fine-grained, red tidal-deltaic lithofacies; BSE); (D) pore-filling and grain-riming hematite in medium- to coarse-grained arkosic sandstone (granular, red fluvio-deltaic lithofacies; PL); (E) pore-lining and grain-coating hematite appearing to predate pore-filling calcite (granular, red fluvio-deltaic lithofacies; BSE); (F) pore-filling and grain-coating hematite. Note hematite between detrital grain contacts and quartz grains and their overgrowths (granular, red fluvio-deltaic lithofacies; PL); (G) cubic and euhedral pyrite in the secondary pores of anhydrite in coarse-grained arkosic sandstone (granular, green deltaic lithofacies; XP); $(\mathrm{H})$ solidified pyrobytumen filling intragranular and intergranular pore spaces in medium- to coarse-grained sandstone (granular, gray-black fluvio-deltaic lithofacies; PL). [QO: quartz overgrowth; XP: cross-polarized; BSE: backscattered electron; PL: plane-polarized; fine-grained: fine-grained sandstone; siltstone + mudstone; granular (medium- to coarse-grained sandstone + conglomeratic sandstone].

Fig. 7. Apparent paragenetic relationship of diagenetic minerals in the FA Formation sediments. Modified from Bankole and others (2015). [a: Bros and others, 1992; b: Bonhomme and others, 1982; c: Gancarz, 1978; d: Ruffenach, 1978].

Fig. 8. Representative XRD patterns of clay-size fractions in the studied samples of the FA Formation. [AD: air-dried; EG: ethylene glycolation].

Fig. 9. Plot of tetrahedral $\mathrm{Al}$ against octahedral $\mathrm{Fe} /(\mathrm{Fe}+\mathrm{Mg}$ ) cations in chlorite (after Curtis and others, 1985). Chlorite structural formula is calculated based on 14 oxygens.

Fig. 10. Binary plots of selected major elements: (A) $\mathrm{SiO}_{2}$ vs. $\mathrm{Al}_{2} \mathrm{O}_{3}$; (B-G) $\mathrm{Al}_{2} \mathrm{O}_{3} / \mathrm{SiO}_{2}$ vs. $\mathrm{CaO} / \mathrm{Al}_{2} \mathrm{O}_{3}, \quad \mathrm{~K}_{2} \mathrm{O} / \mathrm{Al}_{2} \mathrm{O}_{3}, \quad \mathrm{Fe}_{2} \mathrm{O}_{3} / \mathrm{Al}_{2} \mathrm{O}_{3}, \quad \mathrm{TiO}_{2} / \mathrm{Al}_{2} \mathrm{O}_{3}, \quad \mathrm{Na}_{2} \mathrm{O} / \mathrm{Al}_{2} \mathrm{O}_{3}, \quad$ and $\mathrm{MgO} / \mathrm{Al}_{2} \mathrm{O}_{3}$, respectively; (H) $\mathrm{Fe}_{2} \mathrm{O}_{3}$ vs. $\mathrm{FeO}$. Line for stoichiometric composition of magnetite $\left(\mathrm{Fe}_{3} \mathrm{O}_{4}\right.$ : $\mathrm{Fe}_{2} \mathrm{O}_{3} / \mathrm{FeO}=20: 9$ ).

Fig. 11. Plot of U/Th versus total Fe content $\left(\mathrm{Fe}_{\mathrm{T}}\right)$.

Fig. 12. Plot of total iron content (FeT) against (A) $\mathrm{Fe}^{3+} / \mathrm{Fe}_{\mathrm{T}}$; (B) $\mathrm{Fe}$ isotope composition $\left({ }^{56} \mathrm{Fe}\right)$. The gray area, showing ${ }^{56} \mathrm{Fe}=0.00 \pm 0.05 \%$ denotes the ${ }^{56} \mathrm{Fe}$ composition and range of igneous rocks, clastic sedimentary rocks, and the bulk silicate Earth (Beard and others, 2003b; Beard and Johnson, 2004a). Vertical lines at $\mathrm{Fe}_{\mathrm{T}}=6.71 \mathrm{wt} . \%$ represents the average continental crust value (Rudnick and Gao, 2004).

Fig. 13. Plots of (A) $\left(\mathrm{K}_{2} \mathrm{O}+\mathrm{Na}_{2} \mathrm{O}\right) / \mathrm{Al}_{2} \mathrm{O}_{3}$ against $\mathrm{Fe}_{2} \mathrm{O}_{3 \mathrm{~T}} /\left(\mathrm{Fe}_{2} \mathrm{O}_{3} \mathrm{~T}+\mathrm{MgO}\right)$; (B) $\mathrm{Fe}$ isotope compositions $\left({ }^{56} \mathrm{Fe}\right)$ against $\mathrm{Fe}_{\mathrm{T}} / \mathrm{Mg}$. The gray area, showing ${ }^{56} \mathrm{Fe}=0.00 \pm 0.05 \%$, denotes the ${ }^{56} \mathrm{Fe}$ composition and range of igneous rocks, clastic sedimentary rocks, and the bulk silicate Earth (Beard and others, 2003b; Beard and Johnson, 2004a). [H: hematite; I: Illite; KF: Kfeldspar; B: Biotite].

Fig. 14. Fe isotope composition $\left({ }^{56} \mathrm{Fe}_{\mathrm{T}}\right)$ plotted against $1000 * \mathrm{Cr} / \mathrm{Fe}_{\mathrm{T}}$. The gray area, showing ${ }^{56} \mathrm{Fe}=0.00 \pm 0.05 \%$ denotes the ${ }^{56} \mathrm{Fe}$ range of igneous rocks, clastic sedimentary rocks, and the bulk silicate Earth (Beard and others, 2003b; Baeard and Johnson, 2004a). 
1062 Fig. 15. $\mathrm{Fe}^{3+} / \mathrm{Fe}_{\mathrm{T}}$ plotted against $\mathrm{Fe}$ isotope composition $\left({ }^{56} \mathrm{FeT}\right)$. The gray area, showing ${ }^{56} \mathrm{Fe}$ $1063=0.00 \pm 0.05 \%$, denotes the ${ }^{56} \mathrm{Fe}$ range of igneous rocks, clastic sedimentary rocks, and the 1064 bulk silicate Earth (Beard and others, 2003b; Beard and Johnson, 2004a).

1065

1066

1067 Table caption

1068 Table 1 Fe contents and iron isotope compositions of the FA Formation sediments.

1069 Table 2 Summary of Fe isotope composition of Fe sources and fractionation between Fe

1070 species

1071

1072

1073

1074

1075

1076

1077

1078

1079

1080

1081

1082

1083

1084

1085

1086

1087

1088

1089

1090

1091

1092

1093

1094

1095

1096 

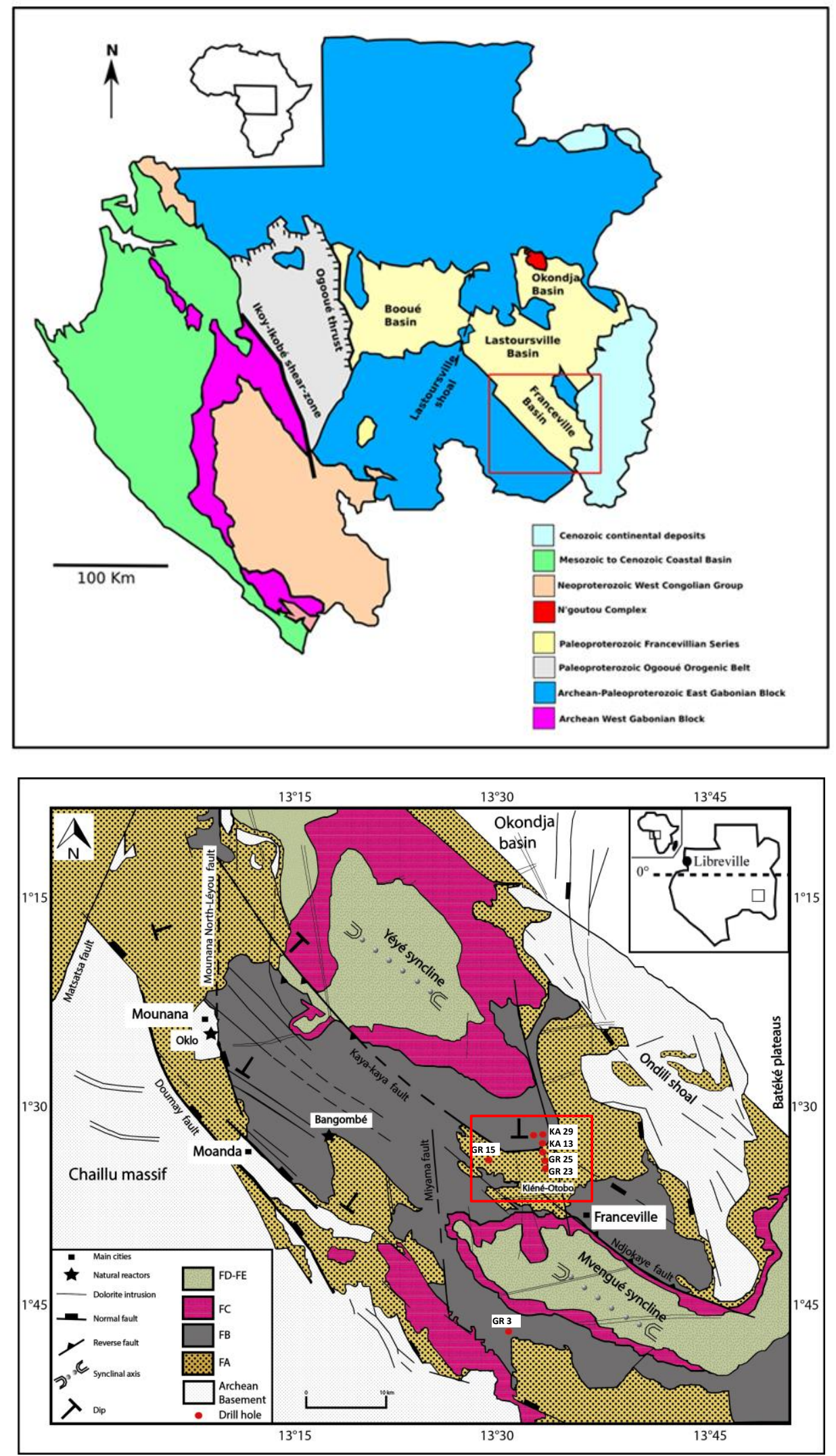


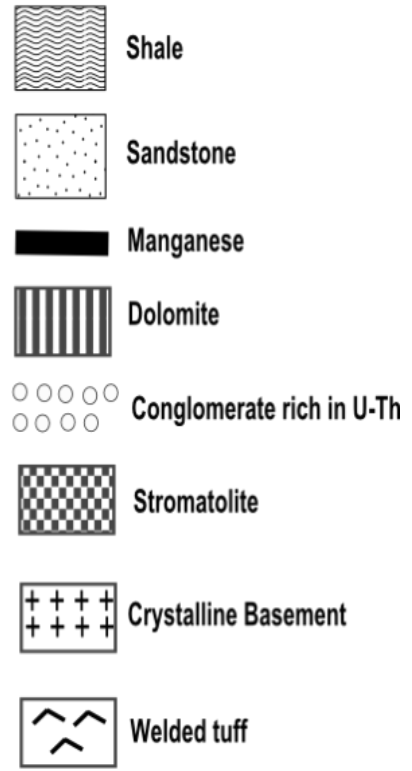

Figure 2

1106 
N

s

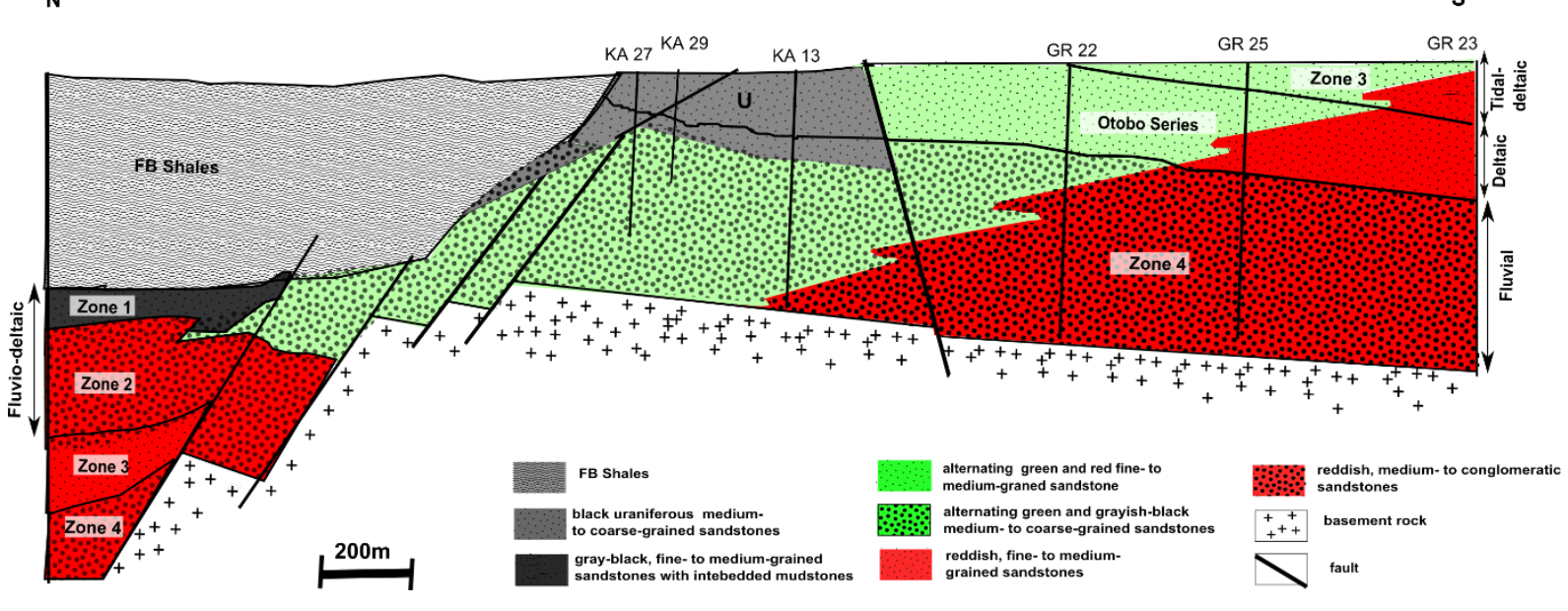

1113

1114

1115

Figure 3

1116

1117

1118

1119

1120

1121

1122

1123

1124

1125

1126

1127

1128

1129

1130

1131

1132

1133

1134

1135

1136 


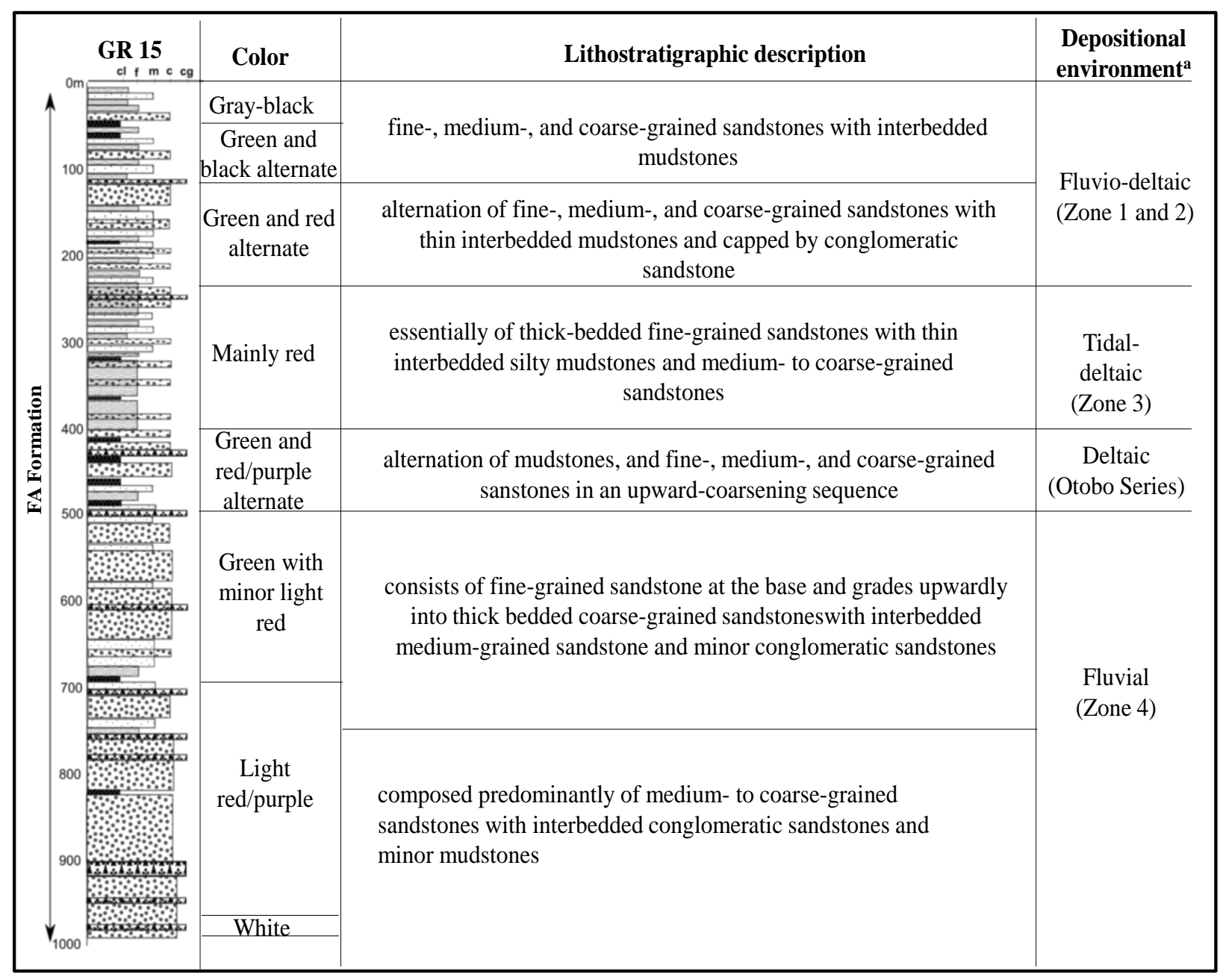

\section{Mudstone}

Fine-grained sandstone

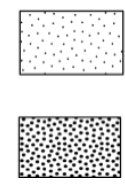

Medium-grained sandstone

Coarse-grained sandstone 


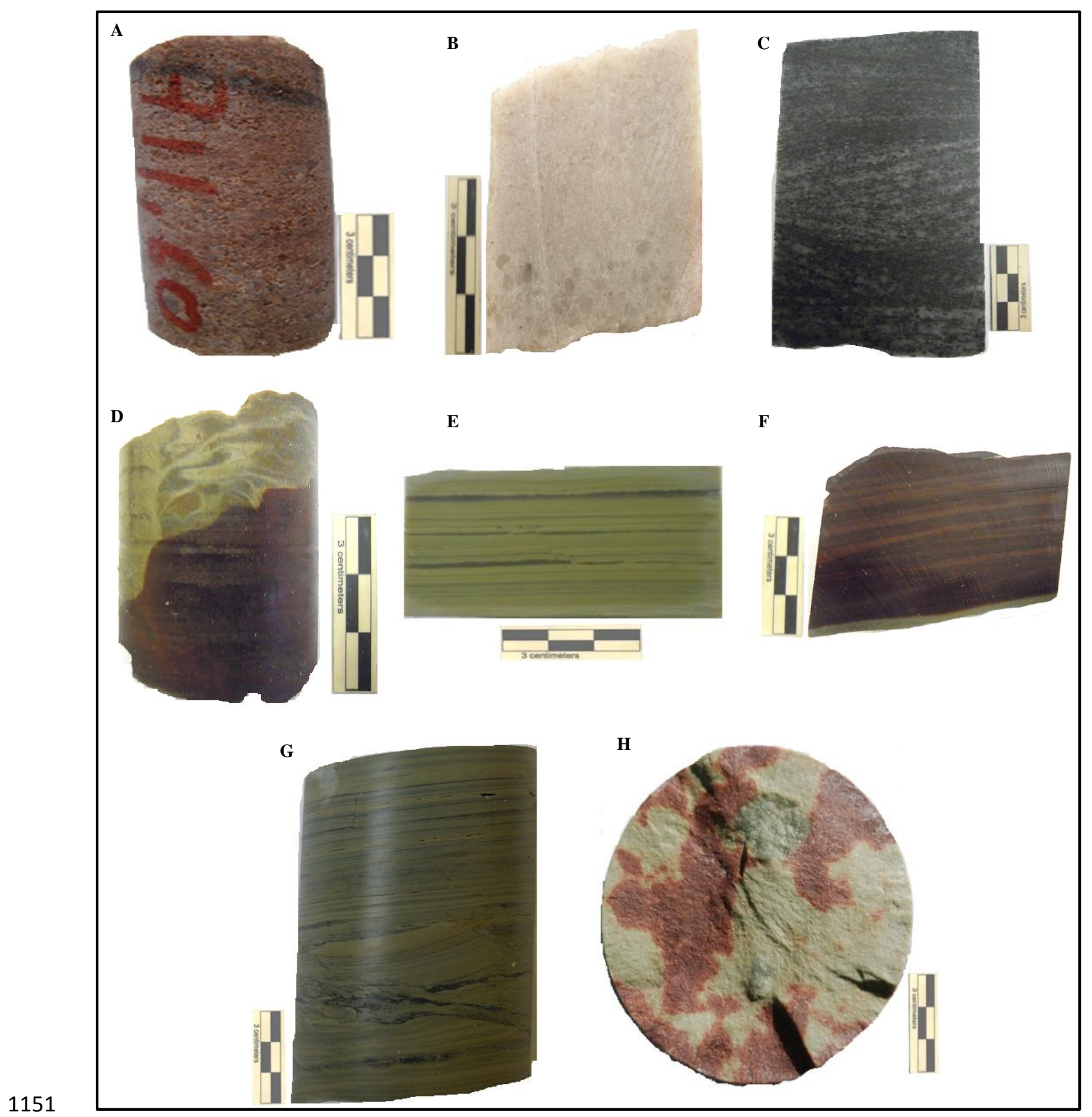

Figure 5

1153

1154

1155

1156

1157

1158

1159 


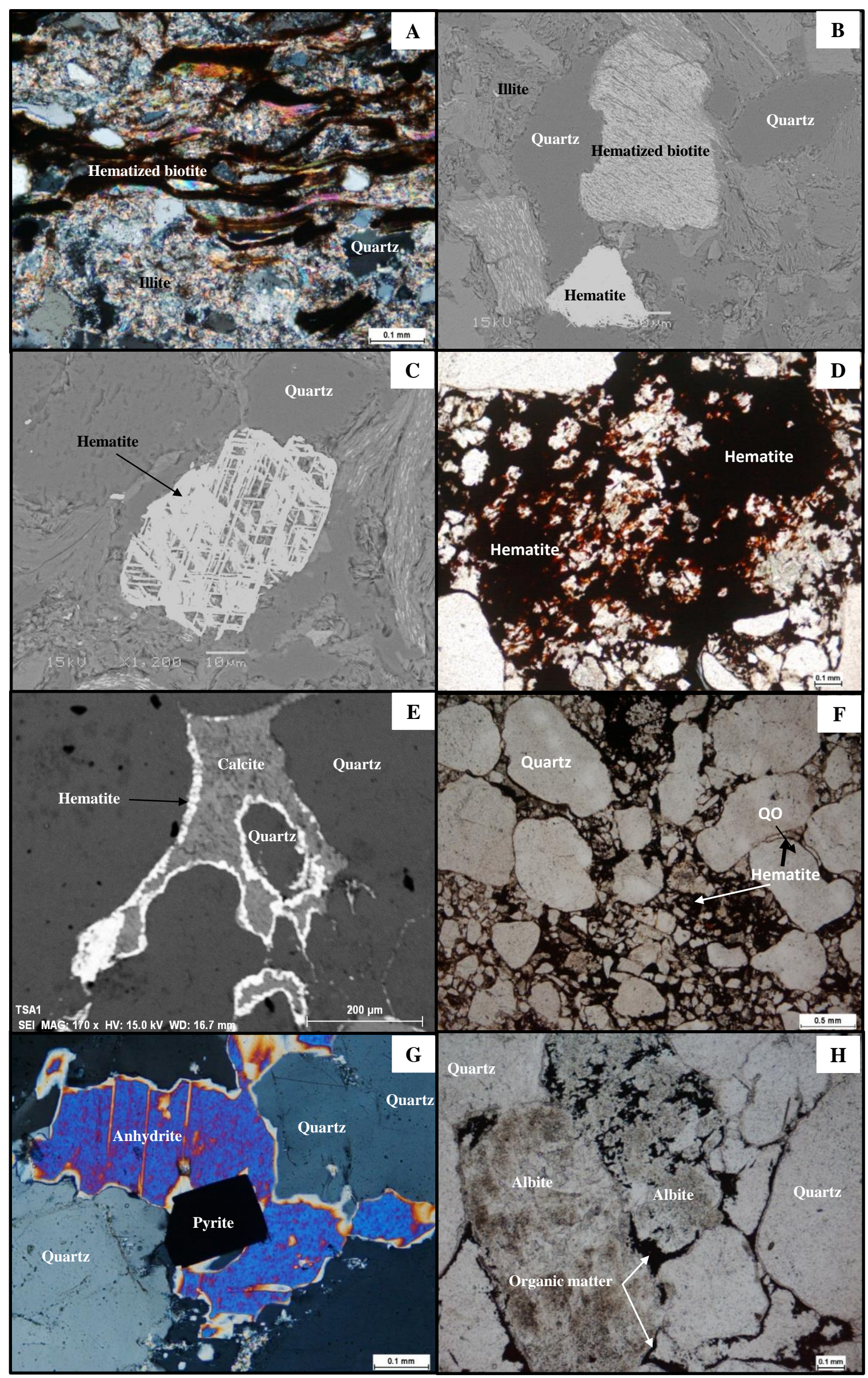

Figure 6 


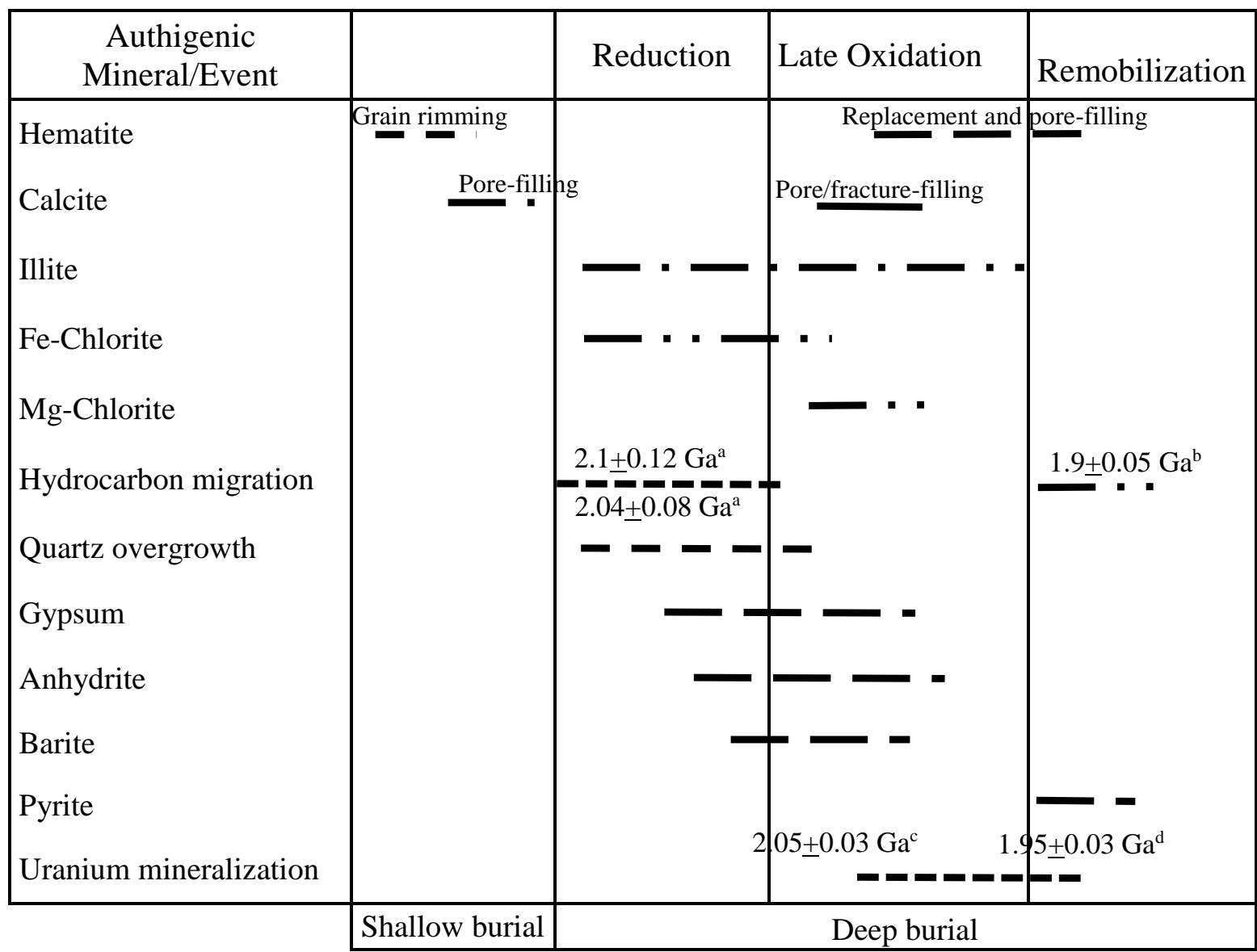




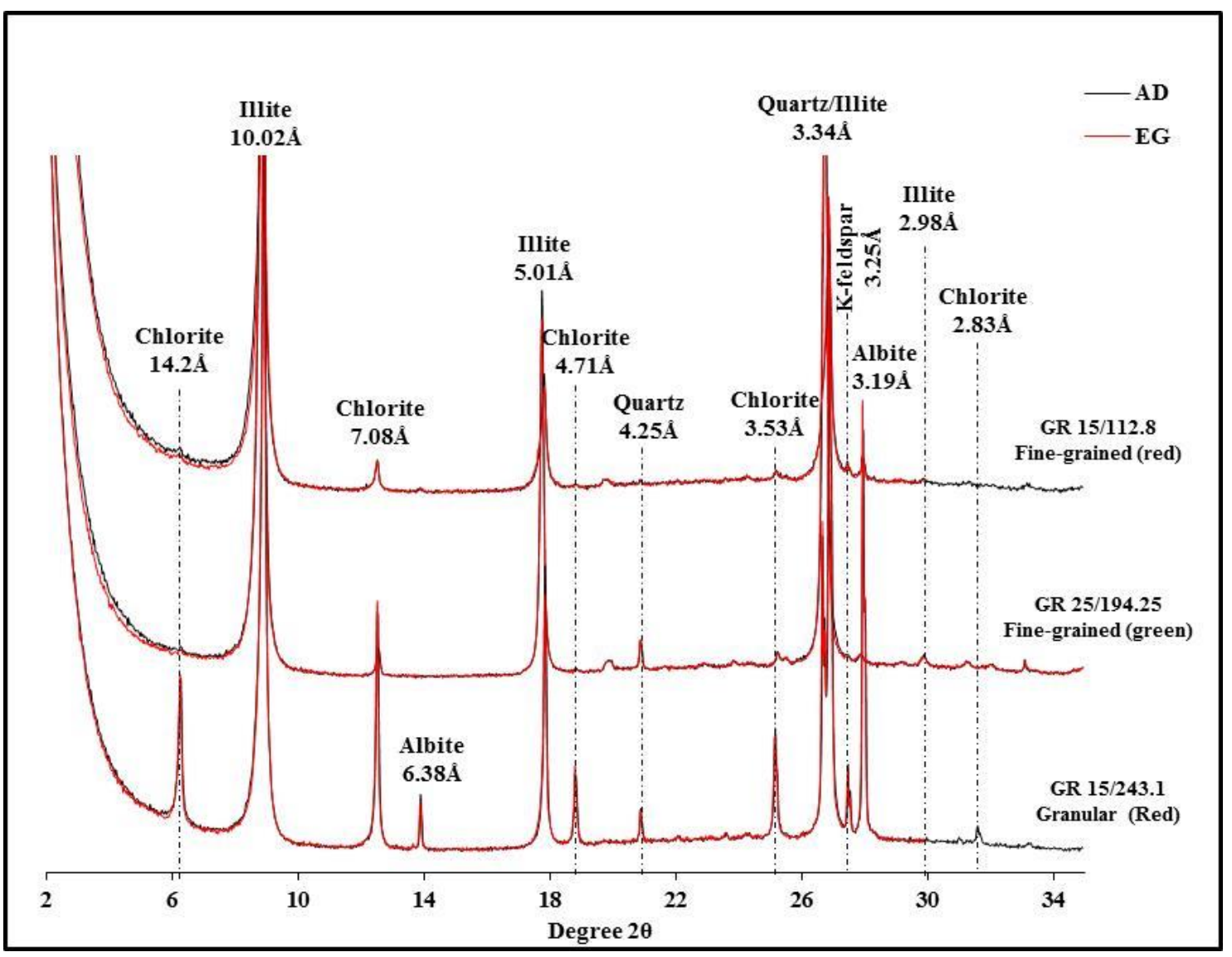

Figure 8

1190

1191 


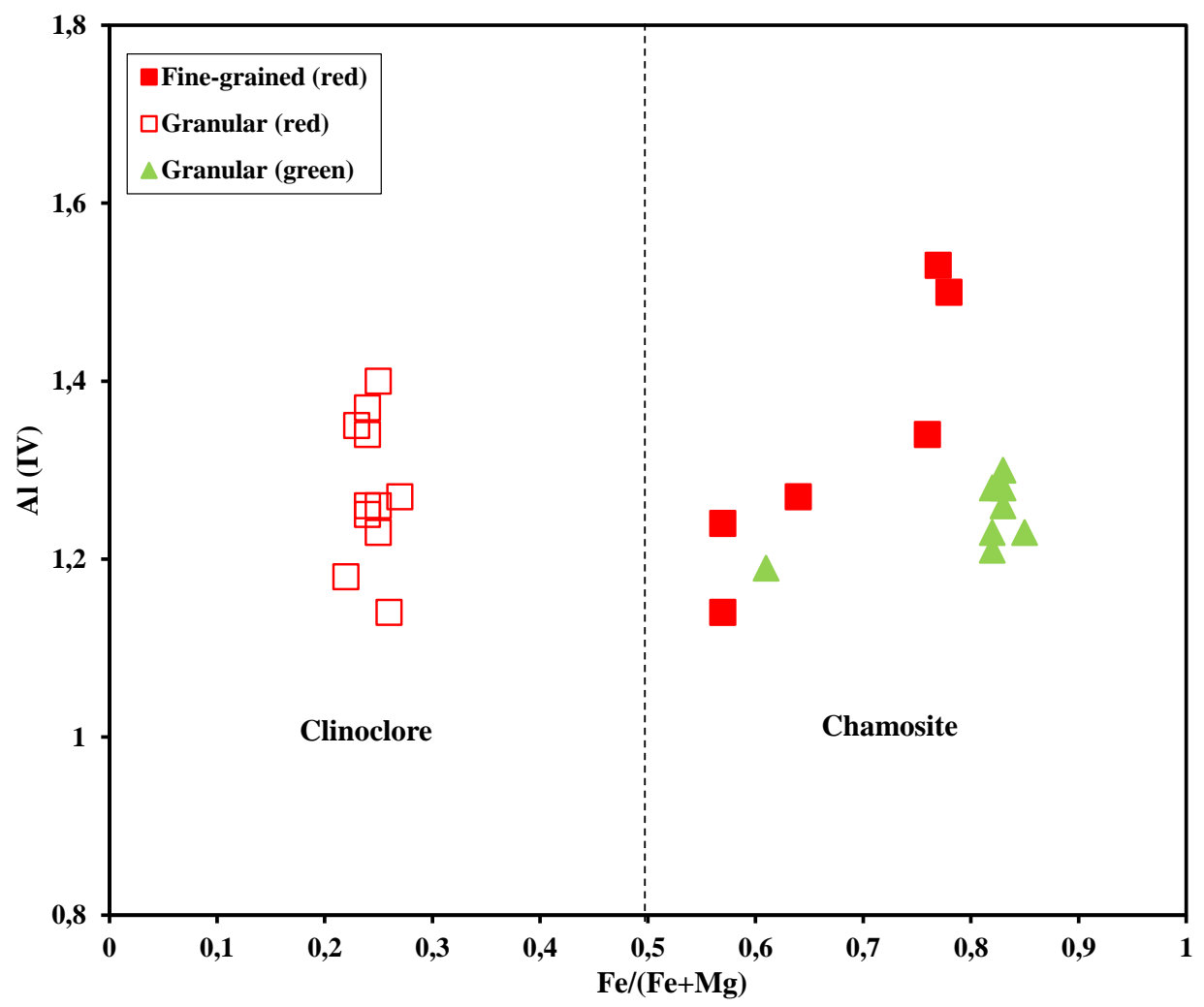

1212

1213

1214

1215

Figure 9

1216 

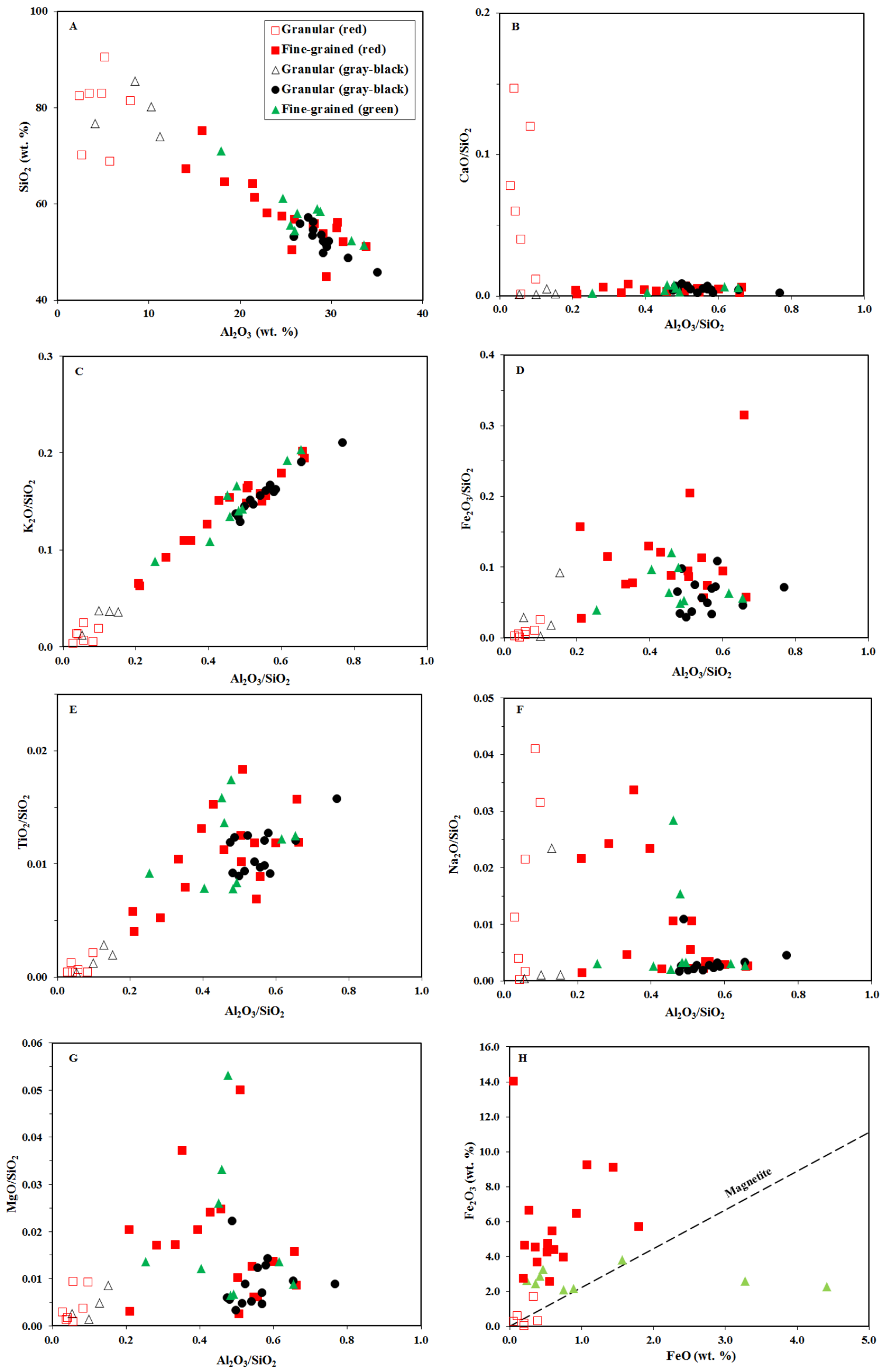

Figure 10 


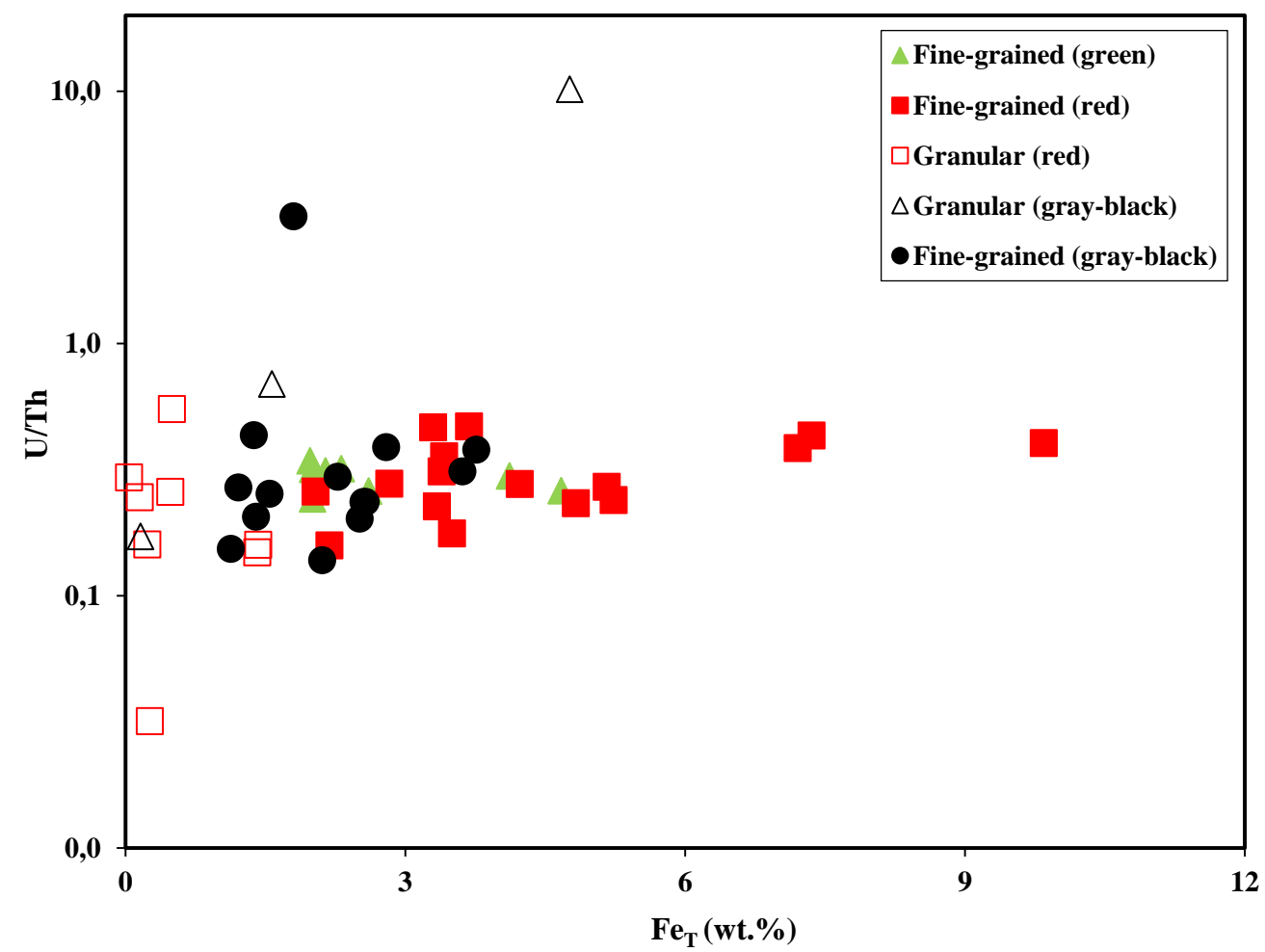

Figure 11

1224 

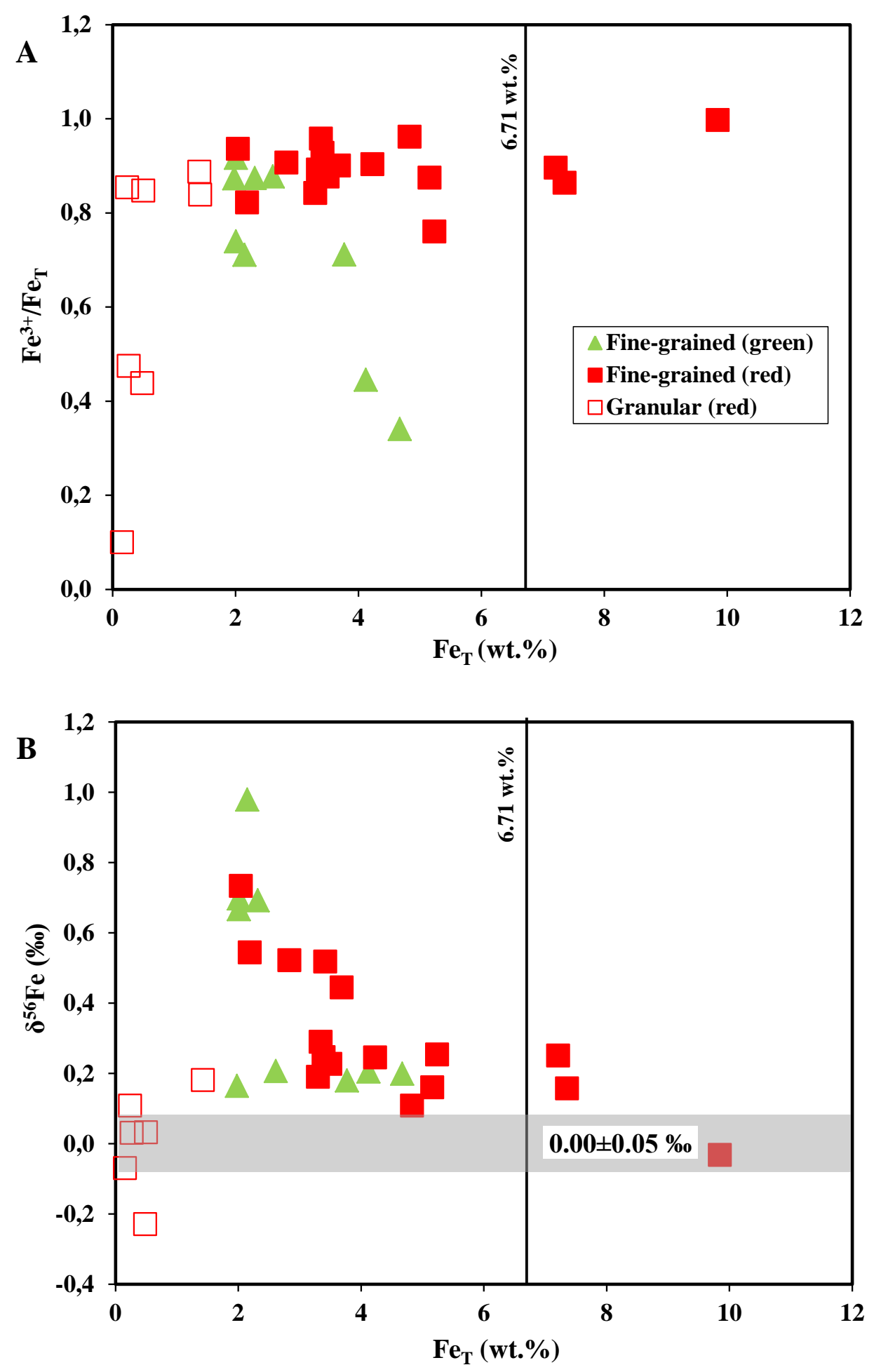

1227

Figure 12 


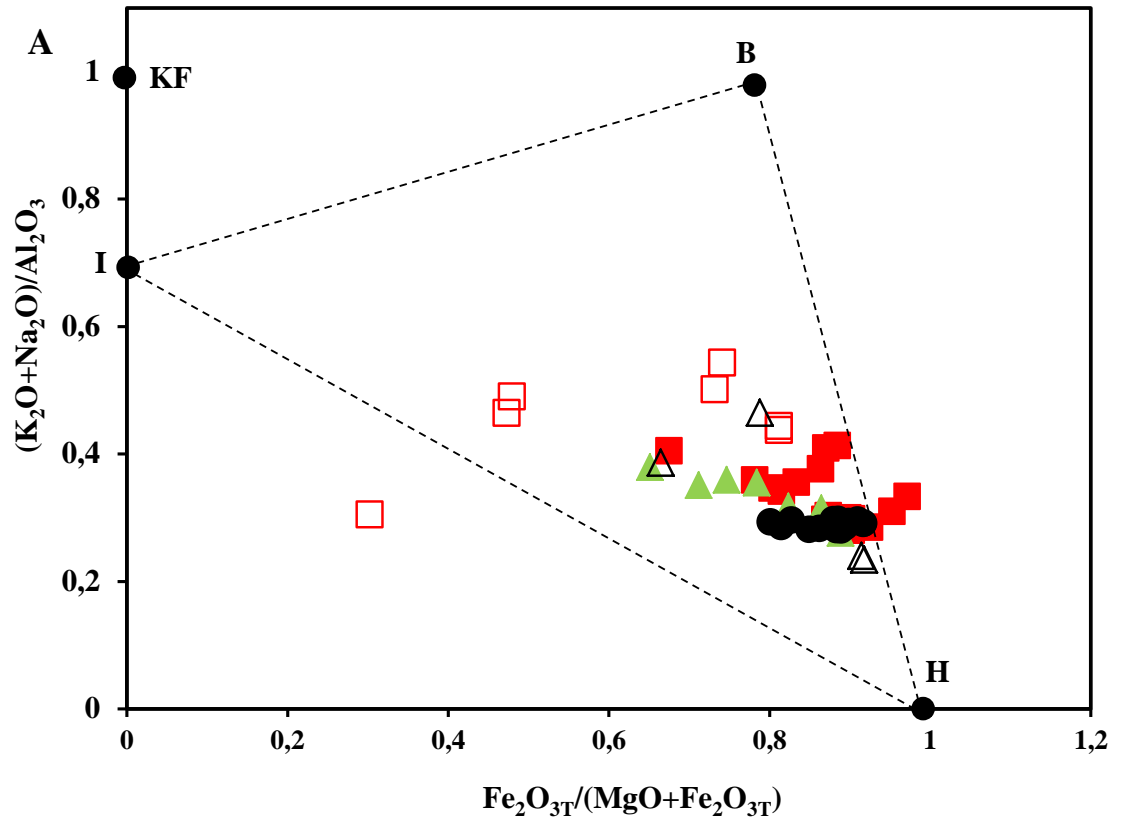

$\square$ Granular (red)

Fine-grained (red)

Fine-grained (green)

$\Delta$ Granular (gray-black)

- Fine-grained (gray-black)

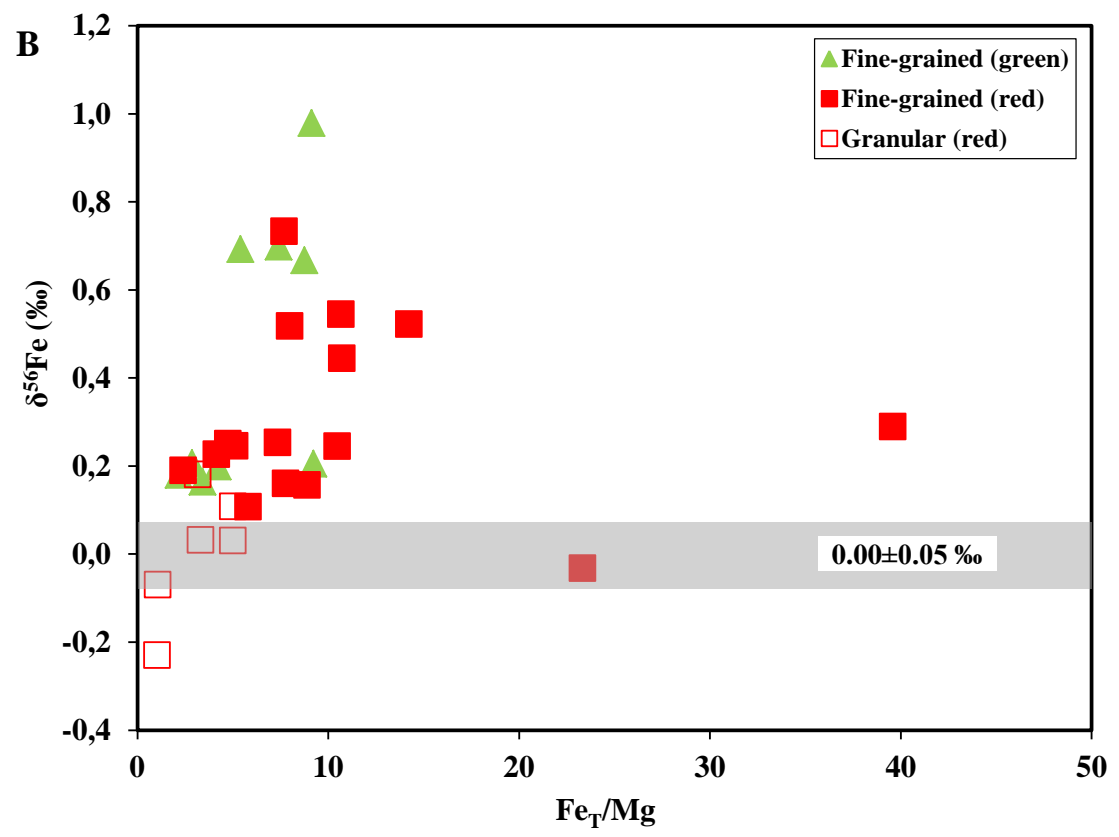

Figure 13

1230 


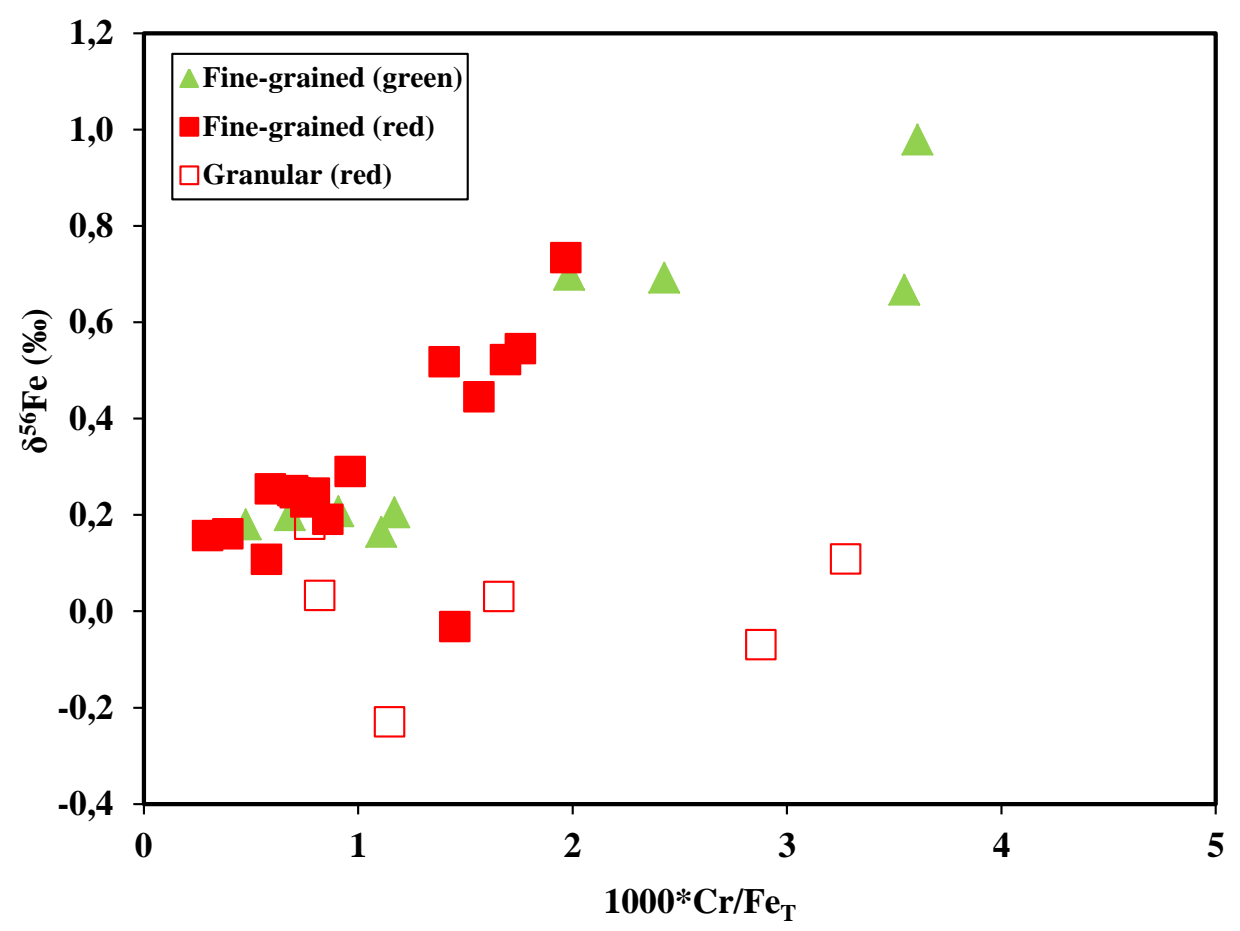

1238

Figure 14

1240

1241

1242

1243

1244

1245

1246

1247

1248

1249 


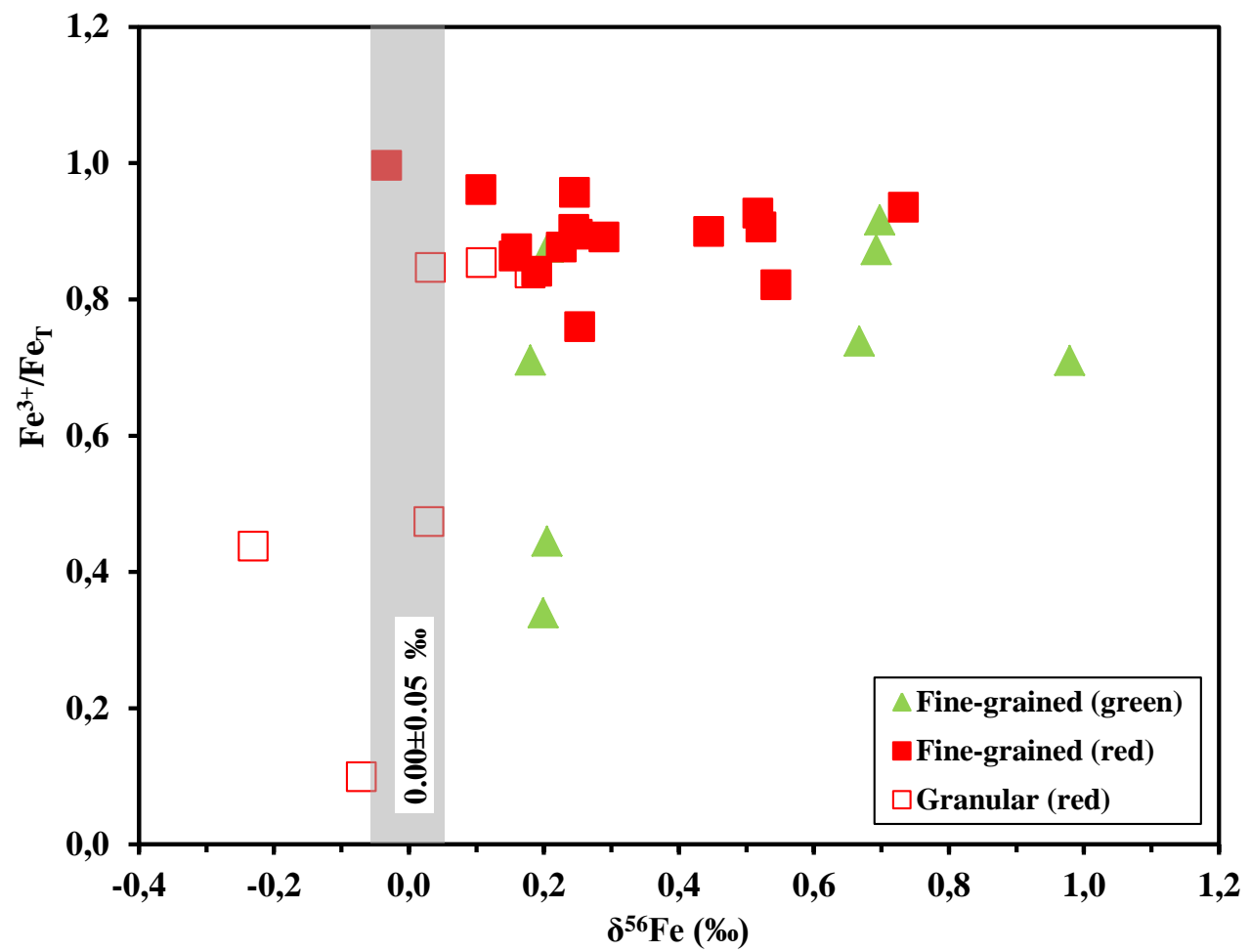

1250

Figure 15

1252

1253

1254

1255

1256

1257

1258

1259

1260

1261

1262

1263

1264

1265

1266

1267

1268

1269 
Table 1

\begin{tabular}{|c|c|c|c|c|c|c|c|c|c|c|c|}
\hline $\begin{array}{l}\text { Drill } \\
\text { hole }\end{array}$ & $\begin{array}{l}\text { Depth } \\
\text { (m) }\end{array}$ & Rock type & Colour & $\begin{array}{c}\mathrm{Fe}^{2+} \\
\text { wt. } \%\end{array}$ & $\begin{array}{c}\mathrm{Fe}^{3+} \\
\text { wt. \% }\end{array}$ & $\begin{array}{c}\mathrm{Fe}_{\mathrm{T}} \\
\text { wt. \% }\end{array}$ & $\begin{array}{c}\mathrm{Fe}^{3+} / \\
\mathrm{Fe}_{\mathrm{T}}\end{array}$ & $\begin{array}{c}\delta^{56} \mathrm{Fe} \\
\% \circ\end{array}$ & $2 \mathrm{SD}$ & $\begin{array}{c}\delta^{57} \mathrm{Fe} \\
\% \circ\end{array}$ & $2 \mathrm{SD}$ \\
\hline \multirow{4}{*}{ GR 15} & 50.90 & \multirow{25}{*}{$\begin{array}{l}\text { Fine- } \\
\text { grained }\end{array}$} & \multirow{9}{*}{ Green } & 3.43 & 1.59 & 4.67 & 0.34 & 0.20 & 0.09 & 0.33 & 0.14 \\
\hline & 250.30 & & & 1.21 & 2.68 & 3.77 & 0.71 & & & & \\
\hline & 416.60 & & & 0.36 & 2.29 & 2.61 & 0.88 & 0.21 & 0.09 & 0.38 & 0.14 \\
\hline & 492.00 & & & 0.28 & 1.73 & 1.98 & 0.87 & 0.16 & 0.09 & 0.34 & 0.14 \\
\hline \multirow{3}{*}{ GR 25} & 194.25 & & & 2.54 & 1.83 & 4.12 & 0.44 & 0.21 & 0.09 & 0.25 & 0.14 \\
\hline & 196.60 & & & 0.58 & 1.48 & 2.01 & 0.74 & 0.67 & 0.09 & 0.96 & 0.14 \\
\hline & 197.40 & & & 0.69 & 1.52 & 2.15 & 0.71 & 0.98 & 0.09 & 1.49 & 0.14 \\
\hline \multirow{2}{*}{ GR 23} & 233.48 & & & 0.19 & 1.84 & 2.01 & 0.92 & 0.70 & 0.09 & 1.05 & 0.14 \\
\hline & 234.10 & & & 0.33 & 2.02 & 2.32 & 0.87 & 0.69 & 0.09 & 1.02 & 0.14 \\
\hline \multirow{8}{*}{ GR 15} & 112.80 & & \multirow{16}{*}{ Red } & 1.40 & 3.98 & 5.24 & 0.76 & 0.25 & 0.09 & 0.42 & 0.14 \\
\hline & 181.00 & & & 0.72 & 4.51 & 5.16 & 0.87 & 0.16 & 0.05 & 0.22 & 0.09 \\
\hline & 250.30 & & & 0.84 & 6.46 & 7.21 & 0.90 & 0.18 & 0.05 & 0.23 & 0.09 \\
\hline & 290.30 & & & 0.58 & 2.78 & 3.30 & 0.84 & 0.2 & 0.05 & 0.3 & 0.09 \\
\hline & 295.80 & & & 1.12 & 6.35 & 7.36 & 0.86 & 0.16 & 0.09 & 0.28 & 0.14 \\
\hline & 416.60 & & & 0.21 & 4.64 & 4.83 & 0.96 & 0.11 & 0.09 & 0.23 & 0.14 \\
\hline & 492.00 & & & 0.16 & 3.25 & 3.39 & 0.96 & 0.25 & 0.09 & 0.41 & 0.14 \\
\hline & 825.75 & & & 0.04 & 9.81 & 9.85 & 1.00 & -0.03 & 0.09 & -0.15 & 0.14 \\
\hline \multirow{2}{*}{ GR 25} & 191.95 & & & 0.30 & 2.57 & 2.83 & 0.91 & 0.52 & 0.09 & 0.71 & 0.14 \\
\hline & 194.25 & & & 0.44 & 1.80 & 2.19 & 0.82 & 0.54 & 0.09 & 0.82 & 0.14 \\
\hline \multirow{4}{*}{ GR 23} & 213.50 & & & 0.46 & 3.82 & 4.23 & 0.90 & 0.25 & 0.09 & 0.43 & 0.14 \\
\hline & 232.80 & & & 0.41 & 3.32 & 3.69 & 0.90 & 0.44 & 0.09 & 0.7 & 0.14 \\
\hline & 233.48 & & & 0.15 & 1.91 & 2.04 & 0.93 & 0.73 & 0.09 & 1.16 & 0.14 \\
\hline & 234.10 & & & 0.28 & 3.17 & 3.42 & 0.93 & 0.52 & 0.09 & 0.77 & 0.14 \\
\hline \multirow{2}{*}{ GR 3} & 571.35 & & & 0.48 & 3.07 & 3.50 & 0.88 & 0.23 & 0.09 & 0.32 & 0.14 \\
\hline & 589.10 & & & 0.40 & 2.98 & 3.34 & 0.89 & 0.29 & 0.09 & 0.45 & 0.14 \\
\hline \multirow{8}{*}{ GR 15} & 243.10 & \multirow{8}{*}{ Granular } & \multirow{8}{*}{ Red } & 0.26 & 1.20 & 1.43 & 0.84 & 0.18 & 0.09 & 0.27 & 0.14 \\
\hline & 282 & & & 0.16 & 0.02 & 0.16 & 0.10 & -0.06 & 0.05 & -0.09 & 0.09 \\
\hline & 312.80 & & & 0.30 & 0.21 & 0.48 & 0.44 & -0.24 & 0.05 & -0.36 & 0.09 \\
\hline & 383.60 & & & 0.09 & 0.42 & 0.50 & 0.85 & 0.03 & 0.09 & 0.10 & 0.14 \\
\hline & 711.60 & & & 0.16 & 0.13 & 0.27 & 0.47 & 0.02 & 0.05 & 0.07 & 0.09 \\
\hline & 900 & & & 0.04 & 0.20 & 0.24 & 0.85 & 0.11 & 0.09 & 0.1 & 0.14 \\
\hline & 976 & & & 0.18 & 1.25 & 1.42 & 0.89 & & & & \\
\hline & 993 & & & & & 0.04 & & & & & \\
\hline
\end{tabular}

1272 Iron isotopic compositions reported using standard delta notations: $\delta^{56} \mathrm{Fe}=\left[\left(\mathrm{R}_{\text {sample }} / \mathrm{R}_{\text {standard }}\right)\right.$ $12731]^{*} 1000$, where $\mathrm{R}={ }^{56} \mathrm{Fe} /{ }^{54} \mathrm{Fe}$, standard=IRMM-14 (Rouxel and others $(2005$, 2008a). S.D: 1274 standard deviation. 
Fe sources and Fe species

Major Fe sources-continental:

Bulk igneous rocks

Phanerozoic weathering products $\delta^{56} \mathrm{Fe}(\%)$

$0.00 \pm 0.05$

$0.0 \pm 0.1$

Beard and others (2003b)

Beard and others (2003a)

Major Fe sources-marine:

Hydrothermal MOR Fe

-0.6 to $-0.3 \quad$ Sharma and others (2001)

Beard and others (2003a)

Fluid-mineral-fractionations- $\mathrm{Fe}^{3+}$ reduction:

$\mathrm{Fe}_{\mathrm{aq}}{ }^{2+}-\mathrm{Fe}^{3+}$ oxide during DIR (equilibrium)

$-1.3 .0 \pm 0.1$

Beard and others (1999, 2003b)

$\mathrm{Fe}_{\mathrm{aq}}{ }^{2+}-\mathrm{Fe}^{3+}$ oxide during DIR (kinetic)

-2.6 to $-1.3 \quad$ Johnson and others (2005)

(equilibrium)

$\mathrm{Fe}_{\mathrm{aq}}{ }^{2+}-\mathrm{Fe}_{3} \mathrm{O}_{4}$ (magnetite) during DIR

$\mathrm{Fe}_{\mathrm{aq}}{ }^{2+}-\mathrm{FeCO}_{3}$ (siderite) during DIR (equilibrium)

-1.3.0 $\pm 0.1 \quad$ Johnson and others (2005)

$\mathrm{Fe}_{\mathrm{aq}}{ }^{2+}-\mathrm{FeCO}_{3}$ (siderite) during abiotic formation

Johnson and others (2005)

+0.4 to 0.6

Wiesli and others (2004)

Mineral-fluid-fractionations- $\mathrm{Fe}^{2+}$ oxidation:

$$
\begin{array}{lcc}
\mathrm{Fe}^{3+} \text { oxide- } \mathrm{Fe}_{\mathrm{aq}}{ }^{2+} \text { - during abiotic oxidation } & +0.9 \pm 0.2 & \text { Bullen and others (2001) } \\
\mathrm{Fe}^{3+} \text { oxide- } \mathrm{Fe}_{\mathrm{aq}}{ }^{2+} \text { - during APIO } & +1.5 \pm 0.2 & \text { Croal and others (2004) }
\end{array}
$$

Aqueous $\mathrm{Fe}^{3+}-\mathrm{Fe}^{2+}$ fractionations at $22{ }^{\circ} \mathrm{C}$ :

$$
\mathrm{Fe}^{3+}{ }_{\mathrm{aq}}-\mathrm{Fe}_{\mathrm{aq}}{ }^{2+}
$$

Welch and others (2002)

$\delta^{56} \mathrm{Fe}$ values are calculated for ${ }^{56} \mathrm{Fe} /{ }^{54} \mathrm{Fe}$ ratios relative to Bulk Earth (see Beard and others, 


\section{Appendices}

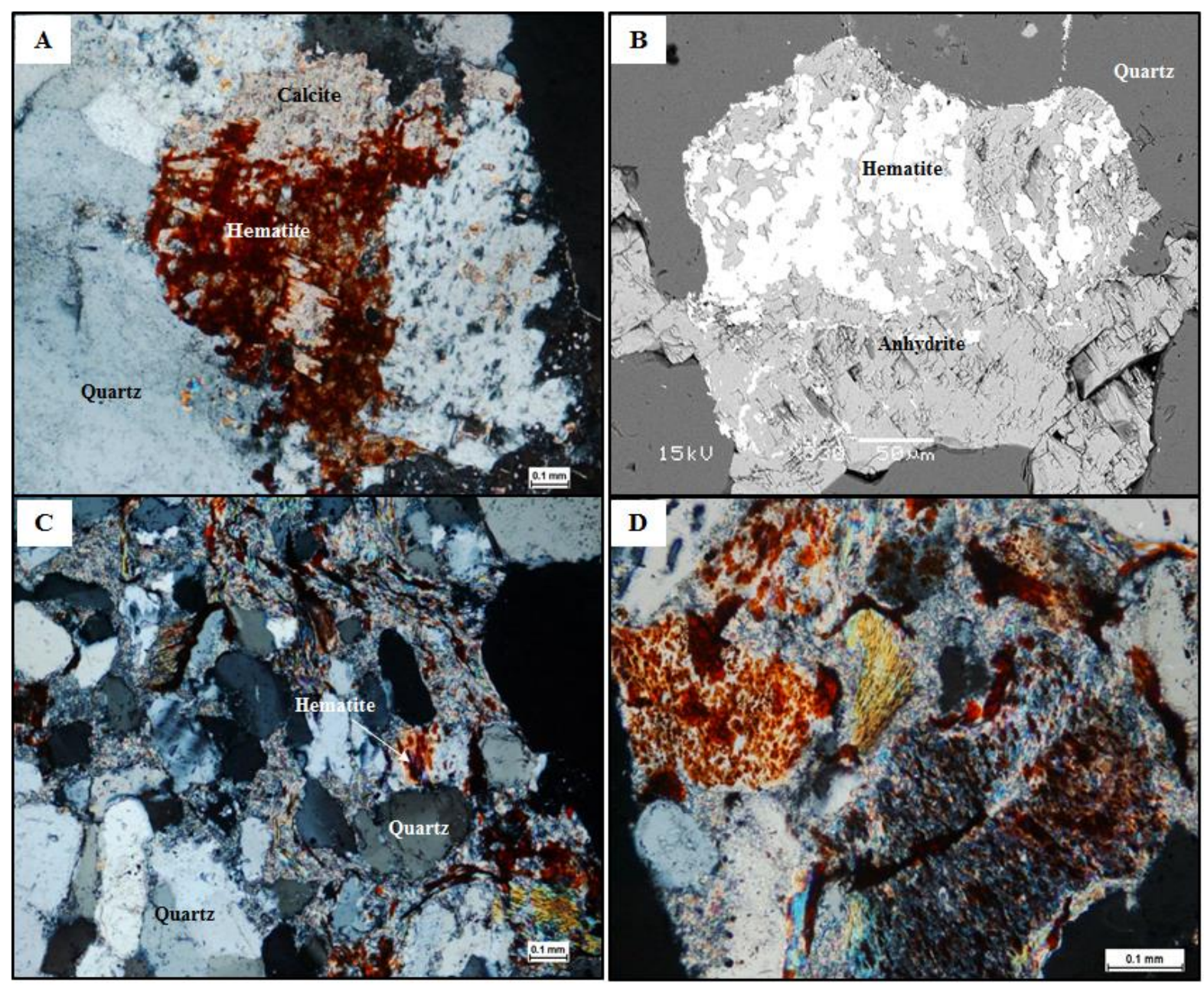

Figure A-1 Photomicrographs of hematite: (A-B) postdating calcite and anhydrite cements in tidal-deltaic lithofacies; (C-D 1292 replacing muscovite along cleavage in the lower fluvial lithofacies. 


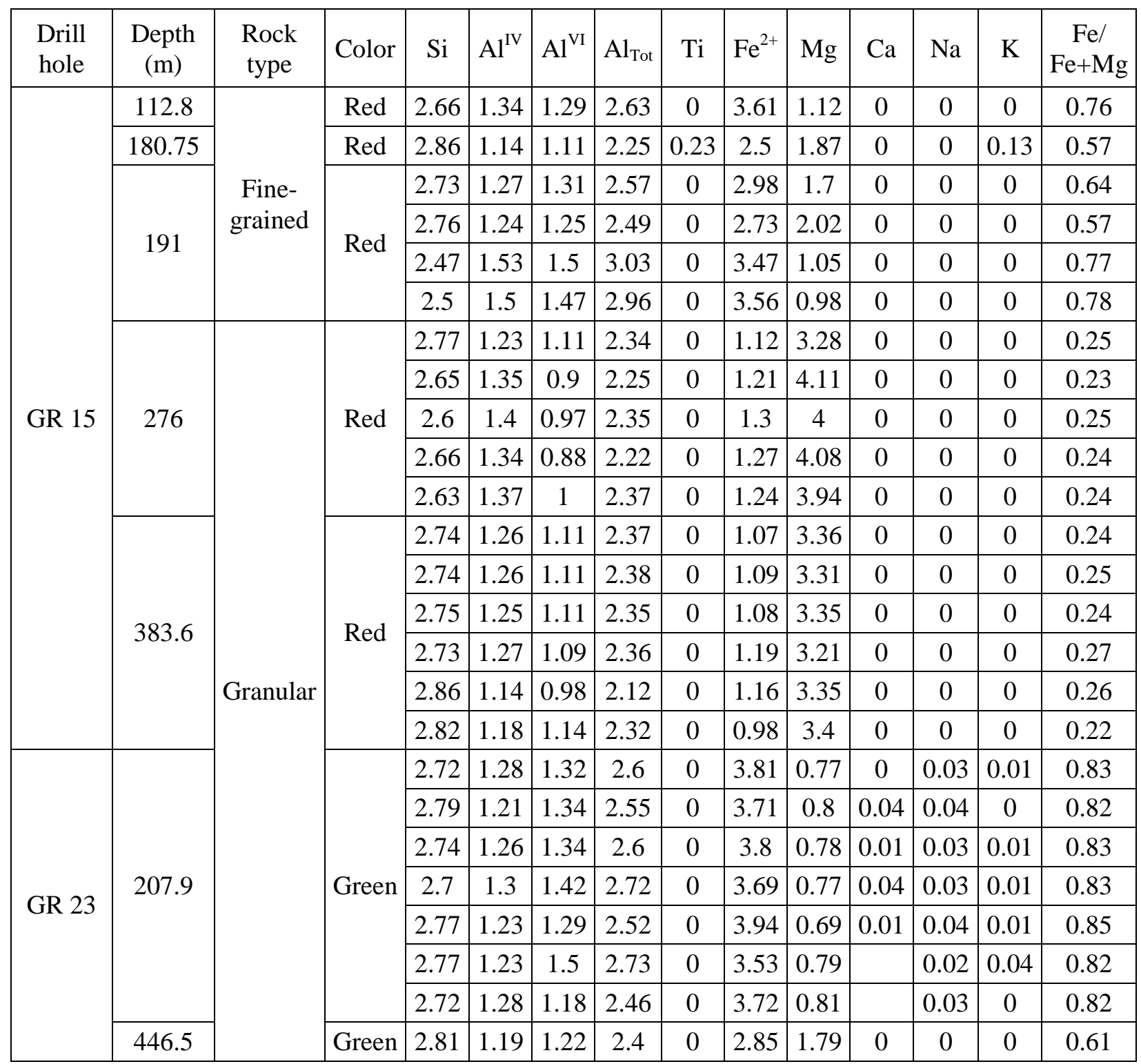

Table A-1 Chemical composition of authigenic chlorite in the red and green parts of the FA Formation (Structural formula was calculated based on 14 oxygen atoms) 
1319

1320

1321

1322

1323

1324

1325

1326

1327

1328

1329 
Table A-2 Geochemical composition of the red beds, FA Formation, Franceville Basin, Gabon

\begin{tabular}{|c|c|c|c|c|c|c|c|c|c|c|c|c|c|c|c|c|c|}
\hline Dri & $\begin{array}{l}\text { ckk } \\
\text { pes }\end{array}$ & $\begin{array}{c}\text { Depth } \\
\text { m }\end{array}$ & $\begin{array}{l}\mathrm{SiO}_{2} \\
\text { wt.\% }\end{array}$ & $\begin{array}{l}\mathrm{Al}_{2} \mathrm{O}_{3} \\
\text { wt.\% }\end{array}$ & \begin{tabular}{|c|}
$\mathrm{Fe}_{2} \mathrm{O}_{3}$ \\
$\mathrm{~T}$ wt. $\%$ \\
\end{tabular} & $\begin{array}{l}\mathrm{MnO} \\
\text { wt.\% }\end{array}$ & $\begin{array}{l}\mathrm{MgO} \\
\text { wt.\% }\end{array}$ & $\begin{array}{l}\mathrm{CaO} \\
\mathrm{wt} . \%\end{array}$ & $\begin{array}{l}\mathrm{Na}_{2} \mathrm{O} \\
\text { wt. } \%\end{array}$ & $\begin{array}{l}\mathrm{K}_{2} \mathrm{O} \\
\text { wt.\% }\end{array}$ & $\begin{array}{l}\mathrm{TiO}_{2} \\
\text { wt.\% }\end{array}$ & $\begin{array}{l}\mathrm{P}_{2} \mathrm{O}_{5} \\
\text { wt. \% }\end{array}$ & $\begin{array}{l}\mathrm{FeO} \\
\text { wt.\% }\end{array}$ & $\begin{array}{l}\mathrm{Fe}_{2} \mathrm{O}_{3} \\
\text { wt.\% }\end{array}$ & \begin{tabular}{|c|}
$\mathrm{Cr}$ \\
$\mathrm{ppm}$ \\
\end{tabular} & $\begin{array}{c}\text { Th } \\
\mathrm{ppm}\end{array}$ & \begin{tabular}{|c|}
$\mathrm{U}$ \\
$\mathrm{ppm}$
\end{tabular} \\
\hline \multirow{8}{*}{ GR 15} & \multirow{16}{*}{$\begin{array}{l}\text { Fine } \\
\text { grained } \\
(\text { Red })\end{array}$} & 112.8 & 58.05 & 23.06 & 7.49 & 0.02 & 1.18 & 0.214 & 1.357 & 7.31 & 0.762 & 0.05 & 1.8 & 5.69 & 31.03 & 20.5 & 4.894 \\
\hline & & 181 & 64.46 & 18.38 & 7.38 & 0.03 & 1.1 & .354 & 1.561 & 5.944 & 0.338 & 0.11 & 0.93 & 6.45 & 20.33 & 11.55 & 3.112 \\
\hline & & 250.3 & 50.38 & 25.74 & 10.31 & 0.05 & 2.52 & 0.336 & 0.53 & 8.365 & 0.923 & 0.07 & 1.08 & 9.23 & 50.27 & 17.56 & 6.752 \\
\hline & & 290.3 & 61.2 & 21.66 & 4.72 & 0.01 & 2.27 & 0.48 & 2.064 & 6.69 & 0.486 & 0.09 & 0.75 & 3.97 & 28.39 & 6.975 & 3.238 \\
\hline & & 295.8 & 67.22 & 14.14 & 10.52 & 0.01 & 1.37 & 0.238 & 1.453 & 4.38 & 0.387 & 0.05 & 1.44 & 9.08 & 21.99 & 16.75 & 7.209 \\
\hline & & 416.6 & 57.32 & 24.64 & 6.91 & 0.03 & 1.38 & 0.183 & 0.116 & 8.628 & 0.874 & 0.11 & 0.27 & 6.64 & 27.71 & 30.48 & 7.068 \\
\hline & & 492 & 64.03 & 21.47 & 4.85 & 0.02 & 1.1 & 0.114 & 0.296 & 7.018 & 0.666 & 0.05 & 0.21 & 4.64 & 24.03 & 14.56 & 4.514 \\
\hline & & 825.75 & 44.72 & 29.5 & 14.08 & 0.03 & 0.7 & 0.072 & 0.114 & 9.006 & 0.703 & 0.05 & 0.05 & 14.03 & 143,0 & 24.47 & 9.833 \\
\hline \multirow{2}{*}{ GR 25} & & 191.95 & 54.83 & 30.67 & 4.05 & 0.01 & 0.33 & 0.253 & 0.187 & 8.526 & 0.487 & 0.19 & 0.38 & 3.67 & 47.85 & 18.67 & 5.175 \\
\hline & & 194.25 & 56.02 & 30.75 & & 0.01 & 0.34 & & 0.193 & 8.393 & & & 6 & 57 & 48 & 68 & 4.536 \\
\hline \multirow{4}{*}{ GR 23} & & 213.5 & 53.69 & 29.2 & 6.05 & 0.02 & 0.67 & 0.252 & 0.117 & 8.471 & 0.635 & 0.17 & 0.59 & 5.46 & \begin{tabular}{|l|}
33.71 \\
\end{tabular} & 22.53 & 6.228 \\
\hline & & 232.8 & 55.83 & 28.21 & 5.27 & 0.01 & 0.57 & 0.303 & 0.119 & 8.269 & 0.699 & 0.21 & 0.53 & 4.74 & 57.66 & 24.86 & 11.63 \\
\hline & & 233.48 & 51.02 & & & 0.01 & 0. & & & 9.909 & 0.607 & 0.19 & 0.19 & 73 & 40.25 & 48 & 5.804 \\
\hline & & 234.1 & 52.07 & 31.33 & 4.89 & 0.01 & 0.71 & & 0.148 & 9.323 & 0.615 & & 0.36 & 4.53 & 47.98 & 25.37 & 9.04 \\
\hline \multirow{2}{*}{ GR 3} & & 571.35 & 56.68 & 26.06 & 5.01 & 0.01 & 1.4 & 0.148 & 0.599 & 8.736 & 0.636 & 0.09 & 0.62 & 4.39 & 26.55 & 21.39 & 3.771 \\
\hline & & 509.1 & 55.27 & 28.09 & 4.78 & 0.02 & 0.14 & 0.161 & 0.302 & 9.045 & 0.562 & 0.11 & 0.52 & 4.26 & 32.24 & 19.63 & 4.428 \\
\hline \multirow{3}{*}{ GR 15} & \multirow{8}{*}{$\begin{array}{c}\text { Fine } \\
\text { grained } \\
\text { (Green) }\end{array}$} & 50.9 & 55.56 & 25.57 & 6.68 & 0.03 & 1.84 & & 1.58 & 7.48 & 0.76 & 0.12 & 4.41 & 2.27 & 31.85 & 14.33 & 3.732 \\
\hline & & 416.6 & 58.03 & 26.28 & 3.73 & 0.01 & 1.51 & 0.19 & 0.12 & 9.09 & 0.92 & 0.12 & 0.46 & 3.27 & 23.68 & 27.76 & 7.207 \\
\hline & & 492 & 70.93 & 18 & 2.83 & 0.01 & 0.96 & 0.11 & 0.22 & 6.24 & 0.65 & 0.06 & 0.36 & 2.47 & \begin{tabular}{|l|}
21.92 \\
\end{tabular} & 9.965 & 3.41 \\
\hline \multirow{3}{*}{ GR 25} & & 194.25 & 61.08 & 24.76 & 5.89 & 0.02 & 0.74 & 0.13 & 0.16 & 6.66 & 0.48 & 0.08 & 3.27 & 2.62 & 48.16 & 24.98 & 7.459 \\
\hline & & 196.6 & 58.83 & 28.49 & 2.87 & 0.01 & 0.38 & 0.3 & 0.19 & 8.24 & 0.46 & 0.22 & 0.75 & 2.12 & 71.23 & 16.06 & 5.081 \\
\hline & & 197.4 & 58.41 & 28.83 & 3.07 & 0.01 & 0.39 & 0.16 & 0.19 & 8.31 & 0.49 & 0.13 & 0.89 & 2.18 & \begin{tabular}{|l|}
77.52 \\
\end{tabular} & 17.8 & 5.551 \\
\hline \multirow{2}{*}{ GR 23} & & 233.48 & \begin{tabular}{|l|}
51.32 \\
\end{tabular} & 33.64 & 2.87 & 0.01 & 0.45 & 0.3 & 0.14 & 10.43 & 0.64 & 0.2 & 0.24 & 2.63 & 39.85 & 22.08 & 5.344 \\
\hline & & 234.1 & 52.32 & 32.28 & 3.31 & 0.01 & 0.71 & 0.32 & 0.16 & 10.07 & 0.64 & 0.19 & 0.42 & 2.89 & \begin{tabular}{|l|}
56.2 \\
\end{tabular} & 31.16 & 9.932 \\
\hline GR 22 & Fine & 47.3 & 54.43 & 28.09 & 2.005 & 0.01 & 0.26 & 0.366 & 0.112 & 8.217 & 0.509 & 0.29 & & & 29.9 & 18.26 & 3.742 \\
\hline
\end{tabular}




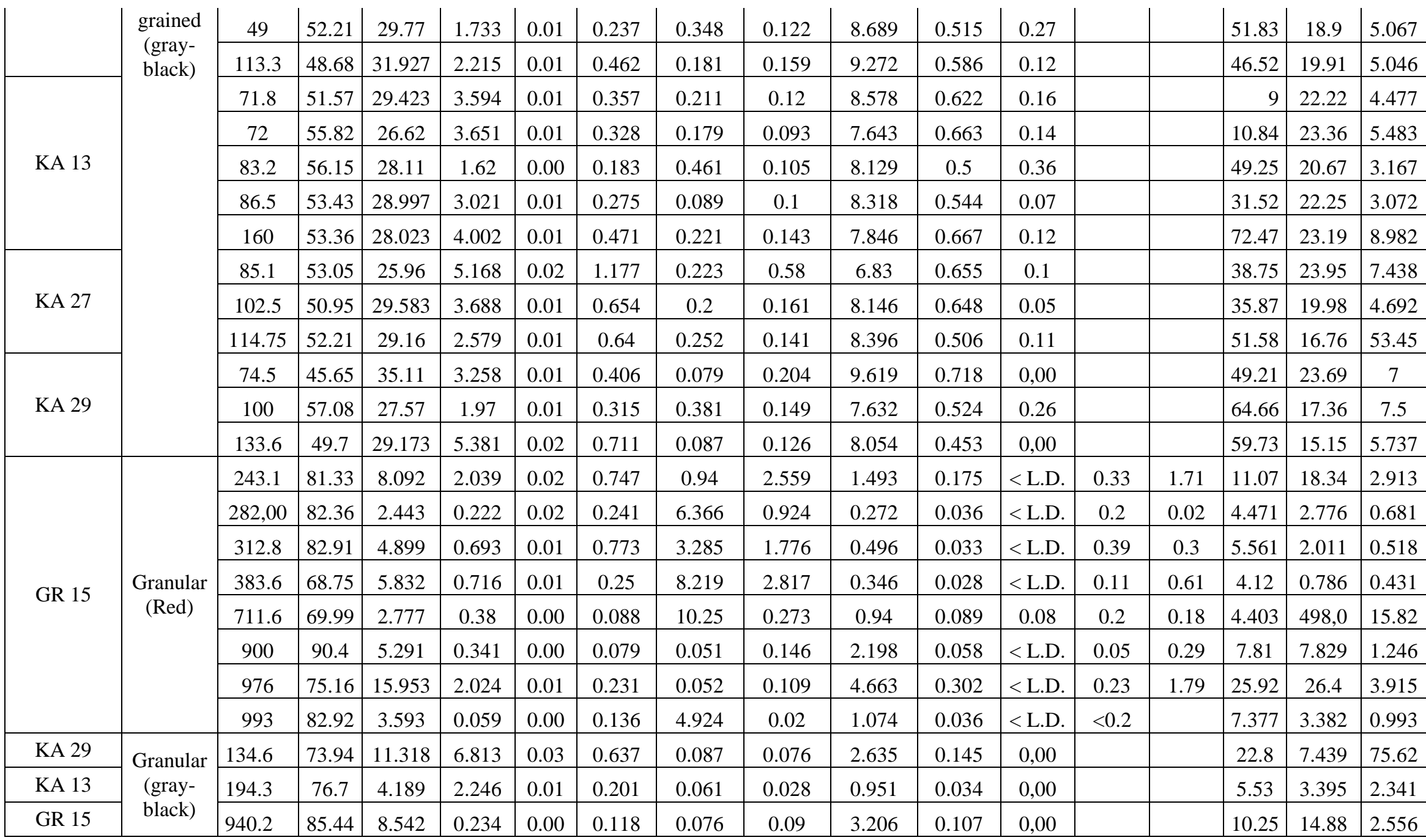

